Article

\title{
Unintended Circularity?-Assessing a Product-Service System for its Potential Contribution to a Circular Economy
}

\author{
Johannes Matschewsky \\ Environmental Technology and Management, Department of Management and Engineering, \\ Linköping University, 58183 Linköping, Sweden; Johannes.Matschewsky@LiU.se; Tel.: +46-(0)-13-28-1635
}

Received: 27 March 2019; Accepted: 29 April 2019; Published: 14 May 2019

\begin{abstract}
Product-service systems (PSSs) are seen as valuable facilitators of a circular economy (CE) on a business level. However, that PSSs contribute to a CE is not a given and is determined by the chosen PSS business model and strategy applied throughout the entire lifecycle. Thus, in order to support companies in implementing circular business models such as PSSs, an increasing number of frameworks and methods have been proposed in prior research. This article hypothesizes that many industrial companies are expanding to become PSS providers with neither such support nor a strong sustainability focus. There is a gap in the literature regarding the potential contribution of such PSSs to a CE. Thus, the research reported aims to provide initial insight regarding whether unintended circularity, i.e., an unintended contribution to a CE, may occur when becoming a PSS provider. Applying and adapting an existing framework for the assessment of PSSs' potential contribution to a CE, the use-oriented PSS of an industrial company was assessed in-depth. Results regarding the relative resource reduction and the prospect of achieving absolute resource decoupling are reported and discussed. While relative improvements over product sales are identified, e.g., resulting from end-of-life efforts on reuse and remanufacturing, opportunities for additional enhancement are found, e.g., in adjustments of the PSS design process. Concerning absolute resource decoupling, a fundamental challenge lies in the use-oriented PSS's dependency on an increasing number of physical components as the company's business expands. This article advances the discussion on PSSs' potential contributions to a CE with an in-depth empirical study. For practitioners, the results reported expand on important aspects of efficient and effective PSS provision throughout the lifecycle.
\end{abstract}

Keywords: Integrated product-service offerings; servitization; sustainable PSS design; lifecycle; resource decoupling; sustainability

\section{Introduction}

Ever since the concept of product-service systems-describing integrated offerings of products and services, designed and provided to satisfy user needs with a lifecycle focus [1] — was proposed two decades ago, a central focus of the research and the related discussion lay on improved environmental performance based on increased resource efficiency and effectiveness [2-4].

The potential benefits gained through resource-efficient and effective product-service system (PSS) design and provision are today increasingly discussed in the scope of an overall effort to establish a new concept for economic activity: A circular economy (CE). In the absence of a concise, agreed-upon definition [5], the term can be described as "an economy that is restorative and regenerative by design and aims to keep products, components, and materials at their highest utility and value at all times" [6] (p. 5). Broadly, a CE is considered an economic model focused on the reduction, reuse, and recycling of resources consumed by economic activity [5,6]. It is seen as a cornerstone towards 
achieving the goals of the Paris Accord [7] and the transition to more sustainable modes of business. In recent years, the scholarly attention on a CE has increased substantially and with a broad set of foci-e.g., a CE's overall conceptualization [5,8-10]; its impact on manufacturing and design [11-14]; supporting business models in general $[2,8,15]$ and product-service systems in particular [16-18]; and CE implementation [19-21].

In this context, PSSs are considered important for the implementation of CE strategies on a company level $[22,23]$ in the scope of circular business models $[13,24,25]$. The expected contribution of PSSs to a more circular way of conducting business originates mostly in the increased responsibility of PSS providers for their offerings throughout the lifecycle and the associated changes in internal business incentives [26-28]. Where a producer and seller of products can profit from high service costs and short product lifespans, a provider in ownership and control of a PSS throughout the use phase will profit from low lifecycle cost and thereby, reduced and more efficient use of material resources.

Realizing the envisaged benefits in industrial practice is by no means a given [17,29]. Instead, it depends on the implementation of a fitting PSS business model [27] and PSS strategy [17,26], and executing these comprehensively throughout all stages of the lifecycle (e.g., through PSS design focused on efficiency and effectiveness [30], efficient PSS provision (for example through data-driven maintenance [31]), and end-of-life (EoL) management with a focus on reuse, remanufacturing and recycling). In this context, efficiency is focused on the narrowing of flows and reducing resource use and pollution [13,32], while effectiveness is centered on intentional and purposeful development towards retaining resource value and maximizing the benefits to ecological and economic systems [6,32,33]. Taking into account both aspects is considered vital for PSSs to contribute to a CE [17]. Companies encounter substantial challenges when carrying out this expansion to effective and efficient PSS design and provision [34,35].

In order to support companies in successfully adopting a circular business model such as PSSs and to alleviate those challenges, several frameworks and methods have been presented $[15,19,20,36,37]$. It is likely, however, that these approaches mostly serve industry actors that, from the outset, have a sustainability-focus with the intention of arriving at a more circular approach for conducting their business or are, in a general sense, aware of the determining aspects and factors. This article hypothesizes that many manufacturing companies are unaware of such support systems. Instead, they likely undergo the process of servitization $[38,39]$ with a focus on traditional, product-centric value generation [34].

The potential unintended contributions to a CE by such unsupported and economically-focused expansions to PSSs are currently unexplored. To contribute to filling this gap, this research aims to provide an initial understanding of the potential contribution to a CE by an economically-driven expansion of an industrial company without the support of CE-centric methods or frameworks. Towards reaching this aim, two questions are to be answered: How can the potential contribution of a use-oriented PSS to a CE be assessed? What is the potential contribution of the PSS offering by the studied company to relative resource reduction and absolute resource decoupling of economic growth and resource use in the scope of a CE?

Towards the proposed aim, an existing framework presented by Kjaer et al. [17] is adopted and expanded with additional, literature-based circular supporting activities intended to facilitate the assessment of the strategy, structure and processes of design, provision and EoL management of a PSS in practice. This extended framework is applied to the use-oriented PSS offered by the industrial company Kamiono, whose expansion to PSSs is driven mostly by a focus on economic benefit and market growth. The company requests to remain anonymous and therefore, both the name and sensitive details regarding the nature of the case company's business had to be redacted. As a provider of use-oriented PSSs, Kamiono remains in ownership and control of the offering and carries out maintenance to ensure availability as agreed upon, while the customer operates the PSS on site (cf. [27]). 
To achieve the desired aim, a broad set of data gathered throughout a research project over five years is assessed. The investigation centered on the design, provision, and EoL management of use-oriented PSSs departing from an engineering focus. As a result, the nature of the data gathered at Kamiono is concentrated on these aspects.

A real-world PSS, developed based on a mostly economic motivation and without prescriptive, CE-centric support, is to be assessed for both its potential to contribute to a relative reduction in resource use and to achieving absolute resource decoupling in the scope of a CE. As a result, the current academic discussion on the possible impact of PSSs as enablers of a CE (see [17]) is to be advanced. Consequently, the preconditions of PSSs potential contribution to a CE should be better understood.

\section{Central Definitions}

To facilitate the ease of reading and to provide clarity, some key definitions will be introduced as they are used in this article. In this, an effort is made to stay close to the terminology used by Kjaer et al. [17] in order to facilitate future research by peers aiming to build on the results attained. Kjaer et al. [17] base their definitions on a report of the United Nations Environment Programme [40].

"Resource decoupling-represents the aim of decoupling economic growth from resource consumption. Resource decoupling seeks to reduce the rate of resource depletion and costs by raising resource productivity, which is expected to reduce environmental impacts simultaneously. Resource decoupling can be relative or absolute" [17,40].

"Relative resource decoupling-focuses on obtaining less environmental damage per growth rate" $[17,40]$. The result is a relative resource reduction. As done in the cases presented in Kjaer et al. [17] (p. 8-10), assessing a resource reduction requires a baseline scenario. Further, the definition broadly refers to overall economic activity and not the individual activities of a company. Therefore, in this article, this baseline is represented by the product sales offering provided by the industrial company Kamiono. Thus, relative decoupling is based on the relation of a PSS offering in comparison to the traditional product sold to a business customer, creating certain customer value through its lifetime. If during its lifetime, a PSS consumes fewer resources (RC) creating the same amount of customer value $(\mathrm{CV})$, relative resource decoupling can be considered to be achieved:

$$
\frac{\sum R C_{\text {Sales }}}{\sum C V_{\text {Sales }}}>\frac{\sum R C_{P S S s}}{\sum C V_{P S S}}
$$

"Absolute resource decoupling-occurs when the resource use declines, irrespective of the growth rate of the economic driver" $[17,40]$. In the scope of the study conducted, this means that the total customer value created is increasing while the total amount of resources consumed to create it through PSSs is decreasing based on a reference point.

\section{Research Method}

This section first lays out the overall research approach. Subsequently, the research method applied both concerning the literature-centric as well as the empirical work conducted is described.

\subsection{Research Approach}

A three-step research approach was adopted. First, a review of academic literature focusing on PSSs and CE was conducted. Here, also broader CE-centric literature was included to arrive at a comprehensive understanding of the status quo.

From the resulting knowledge database, key circular supporting activities intended to facilitate the assessment of PSSs' potential to contribute to relative resource decoupling towards a CE were developed with a focus on key phases of the lifecycle and concentrating on use-oriented PSS. The degree to which these activities are carried out in practice is intended to indicate the potential CE contribution of a use-oriented PSS. The framework for the assessment of PSSs' potential contribution to 
resource reduction in the scope of a CE presented by Kjaer et al. [17] was identified during the review. This framework was used as a basis and adjusted with the identified activities to enable a focused but comprehensive assessment of the potential contribution of Kamiono's use-oriented PSS to relative and absolute resource decoupling in the scope of a CE. The goal was to operationalize the pre-existing framework to support future assessments along the same lines by peers in the field.

In a third step, the PSS provision of Kamiono was assessed in relation to the framework with respect to relative and absolute resource decoupling in the scope of a CE. Lastly, lessons learned, and ways forward were reported, indicating broadly relevant insight for practitioners and interesting questions for continued research. Figure 1 condenses and illustrates the overall research approach.

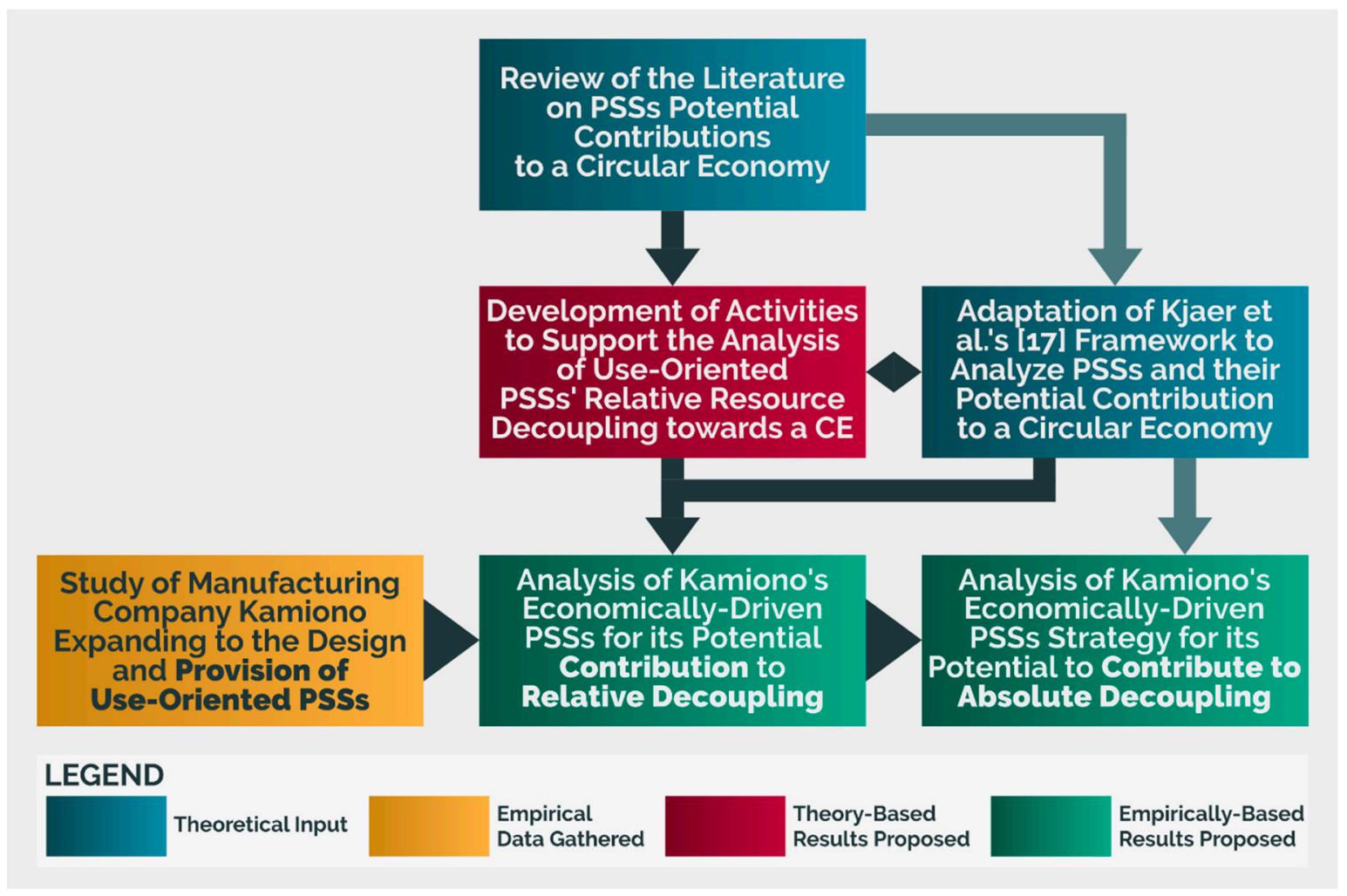

Figure 1. Research approach.

\subsection{Literature Review}

The research relevant to reaching the aim of this paper is dispersed over a variety of fields, with a broad set of terminology in use. Due to that, instead of a systematic literature review with fixed search terms at a given point in time, a narrative review was carried out [41], aiming to ensure the nuances of PSSs in a CE context were taken into consideration. Restricting the focus explicitly to the aspect of PSSs as a circular business model [24], a substantial part of the broader research focusing on a CE is out of scope. Regardless, care has been taken to ensure that important lessons learned that appear not immediately related to PSSs are considered.

An initial literature search was performed in Scopus, ScienceDirect, and Google Scholar using the keywords PSS, PSSs, product-service systems, product/service systems, integrated solutions, functional sales, circular business models, design, provision, operation, remanufacturing, servitization and circular economy, both individually and in conjunction, to achieve an overview of the field. While the focus lay on peer-reviewed journal articles, relevant, high-quality conference publications were included in the selection. The research items identified were then sorted into first and second-order references based on assessing the title, keywords, abstract, introduction, and conclusion. In this, first-order references were immediately relevant to isolating activities to support the assessment of 
PSSs' real-world contribution to resource reduction in the scope of a CE, while second-order references served to provide an understanding for the broader $\mathrm{CE}$ context and were utilized in the research presented. Throughout the keyword-based search, both an up- and downstream snowballing approach was taken: For upstream snowballing, the citing documents of the publication were investigated in Google Scholar. For downstream snowballing, the references of the publication in question were reviewed and included if deemed relevant.

\subsection{Identifying an Assessment Framework and Establishing Assessment Criteria through Circular Supporting Activities}

In the context of the narrative literature review, a highly relevant, recent publication in the context of PSSs and a CE emerged: Kjaer et al.'s [17] proposal of a framework to assess PSSs' possible contribution to a $\mathrm{CE}$ both regarding relative and absolute resource decoupling. This constitutes, to the author's knowledge, the only available framework exclusively centered on the assessment of PSSs' potential to contribute to a CE. Other approaches, such as the "ReSOLVE Framework" [37], were considered overly broad, while the evaluation framework for $\mathrm{CE}$ business models proposed by Manninen et al. [15] assumes an environmental value proposition unfit for this study. The business model framework for sustainable consumption proposed by Tunn et al. [42], albeit again focused on companies aiming to conduct their business more sustainably, may have been fitting to analyze Kamiono's current strategy, processes, and structure. However, the literature review was carried out and work on the assessment had commenced in August of 2018, when Tunn et al.'s [42] framework was not yet published.

To further operationalize Kjaer et al.'s [17] framework and to facilitate and clarify the assessment of the strategy, processes, and structure of PSS providers throughout the lifecycle, this framework was operationalized with additional, industry-centric circular supporting activities. The degree to which these supporting activities are applied in practice was used as a criterion to indicate the potential contribution of the industry PSS to relative resource decoupling in the scope of a CE. Adaptations of the proposed framework were explicitly invited by the authors [17], and in turn, peers are invited to reflect and adjust based on the additions proposed here.

These circular supporting activities and their descriptions were developed based on the literature background established and then slightly modified to be seamlessly applied in the scope of Kjaer et al.'s [17] framework with a particular focus on facilitating the assessment of the potential CE contribution of a use-oriented PSS. In developing the supporting activities, the focus lay as much as possible on capturing the real-world impact of designing and providing PSSs on relative resource decoupling resulting from the company's strategy, structure, and processes. These supporting activities encompass approaches, initiatives and business actions that have been found in prior research to potentially increase the circularity (i.e., contribution to a CE) of PSSs. Assessing the degree to which a company applies these activities supports drawing conclusions regarding the potential CE contribution of a PSS offering.

Ideally, the extent to which the case company carries out these supporting activities could be shown in quantitative terms, showcasing, e.g., a percentage of compliance and thus elucidating the remaining improvement potential. As such an assessment can never be exact and would provide a false sense of preciseness, a qualitative comparison between the criteria indicating PSSs' possible contribution to resource decoupling in the scope of a CE and the Kamiono case was chosen. However, the performance of the PSS investigated is discussed in relation to Kamiono's traditional product sales offerings. This intends to provide a clearer image of the potential contribution of this use-oriented PSS to resource decoupling in a CE in contrast to a baseline typical for industrial companies with a background in producing and selling products. In addition, a four-point scale was developed to provide at-a-glance insight on the potential contribution to relative resource decoupling dependent on the degree to which a given activity is implemented in practice. However, this is merely intended to 
provide superficial insight and a deeper, qualitative analysis of the supporting activities in PSS practice is needed in any case.

\subsection{The Kamiono Study}

Kamiono is a supplier of industrial equipment to business customers of all sizes in Europe. In the late 1990s, the company commenced its journey towards becoming a provider of PSSs. Today, the majority of Kamiono's revenue is based in use-oriented PSS offerings. Accelerated by Internet of Things technology, parts of the company are directing their progress towards providing result-oriented PSSs in the future.

The data evaluated here was collected as part of a five-year project (2014-2018) funded by Kamiono, which was initially not centered on a CE context. Rather, the project and the data-gathering activities throughout were focused on achieving a more profound understanding of how cost and value perspectives change as a company moves from solely being a product seller to becoming a provider of PSSs. First and foremost, the attention lay on understanding lifecycle cost and value capture and creation, using a mostly descriptive approach. For the results presented here, the data gathered in the value context was evaluated, as the related project tasks were carried out by the author. However, insight from investigations on both lifecycle cost and changes in value creation and -capture fed into the data reported, resulting from the summary workshops with earlier project participants and additional practitioners.

As the topic of value creation and capture through PSSs pertains to the entirety of Kamiono's business, a large number of respondents throughout the organization were involved in the data gathering, internal dissemination, and discussion of the results (e.g., practitioners in product development, service, and PSS management; see Table 1). As a result of the empirical work, a comprehensive understanding of Kamiono's PSS strategy, structure, and processes throughout the design, provision and EoL management of PSSs was developed. The data collected was complemented in some instances by freely available information to provide a holistic overview of Kamiono's PSSs offerings even beyond the topics in the empirical focus of the project. To ensure Kamiono's anonymity, these sources in gray literature cannot be referenced.

Table 1. Data-gathering efforts and respondents at Kamiono.

\begin{tabular}{|c|c|c|c|}
\hline $\begin{array}{l}\text { Research } \\
\text { Method/Data-Gathering } \\
\text { Approach }\end{array}$ & Timeframe & Respondents & $\begin{array}{l}\text { Total Number } \\
\text { of Sessions }\end{array}$ \\
\hline Actor Maps & 2014-2015 & $\begin{array}{l}\text { Product designer, Head of department } \\
\text { product design, Project coordinator, } \\
\text { Early-stage design engineer, } \\
\text { Environmental coordinator }\end{array}$ & 5 \\
\hline Interviews & 2014-2017 & $\begin{array}{l}\text { Product Development (e.g., R and D } \\
\text { Leader; Project leader; Project Manager; } \\
\text { Design Manager; Design Group Leader; } \\
\text { Quality Engineer), Service (e.g., } \\
\text { Business Development Manager; } \\
\text { Service Leader; Service Coordinator), } \\
\text { PSS Management (e.g., Project Leader } \\
\text { Product Data; Project Buyer; Senior } \\
\text { Manager), Product Management } \\
\text { (Product Group Manager; Product } \\
\text { Manager), Sales (e.g., Salesman; Key } \\
\text { Account Manager) }\end{array}$ & 19 \\
\hline Focus groups & 2016-2018 & All of the above. & 4 \\
\hline
\end{tabular}




\subsection{Research Methods Employed for Empirical Data Gathering and Compilation}

Table 1 provides an overview of the research methods and data-gathering approaches employed and the positions of practitioners involved in the research.

\subsubsection{Actor Maps}

At the outset of the research, actor mapping was used to gain an overview and understanding of the internal processes, relationships and interactions within Kamiono concerning design, provision, and end-of-(first)-life management of its offerings. A key focus in this was investigating the (possible) impact of information (e.g., on frequently needed repairs or replacements and the associated improvement opportunities) gathered during Kamiono's remanufacturing efforts in the EoL management on the design process.

To this end, respondents (see Table 1) elaborated on their working interactions, flows of information to and from other actors with the company, and the way they work and contribute to the design and provision of PSSs. This information was mapped out on paper or a whiteboard, using different colors to structure the data gathering. Actor maps have been applied to gain an in-depth understanding of internal processes with a design focus in prior research in various companies [43,44].

\subsubsection{Interviews}

Interviews were carried out to gain comprehensive insight on Kamiono's processes of design and provision of PSSs, particularly with a focus on value creation and value capture through these offerings. Based on this effort, an in-depth understanding of the current and past strategy, structure and processes of PSS design, sale, provision, and EoL management was achieved. A broad set of respondents (see Table 1) was involved in this effort.

All interviews carried out were semi-structured expert interviews supported by interview guides (cf. Flick [45] (p. 165)), and all departed from a focus on Kamiono's value capture and generation. Seven of the interviews were supported by a step-wise approach used together with the respondent, aiming to structure the data gathering and to increase the comparability of the results. The remaining twelve interviews omitted such a rigid structure for a general interview guide. Additional insight was gathered through pre-interview questionnaires sent to 12 design and management-focused respondents of the 19 interviewees (see Table 1), which aimed to identify the respondents' understanding of value creation and value capture through product sales and PSSs before the interviews (cf. Flick [45] (p. 164)). Whenever possible, the interviews were carried out by two interviewers.

\subsubsection{Focus Groups}

The focus group sessions served to consolidate the lessons learned throughout the extensive research project, and to isolate pressing issues regarding Kamiono's servitization, PSS design, provision, and EoL management from the viewpoint of the practitioners within the company and to ensure the understanding attained through interviews prior was comprehensive and correctly weighed. Further, a central goal was disseminating the results of the research conducted to relevant and interested staff.

Focus groups typically consist of six to ten participants [46] (p. 385). As two of the workshops had a notably higher number of participants, groups were formed for individual discussions, which were then taken up for a joint discussion and review towards the end of the workshop. All workshops commenced with a short presentation of the research results, and subsequently, the participants were assigned tasks and discussion topics. For two of the workshops, A3-sized sheets were provided to support the discussion and facilitate the recording of results, while in the remaining two, no such structure was provided. The focus group format was selected as it allows for broader, simultaneous discussions with a larger number of practitioners in the interest of cost- and time-efficiency [47] (p. 5). 


\subsubsection{Data Compilation and Analysis}

All data gathering sessions were audio-recorded and digitally stored. These recordings were either transcribed in full or evaluated and subsequently selectively transcribed [45] (p. 300). For the dissemination of the research results to the case company and their application in other publications and reports, the data gathered was coded through open coding, using analyst terms $[48,49]$ as cited (in [45], p. 307ff.). This resulted in a collection of coded quotes, providing an extensive overview of Kamiono's strategy, structure, and processes to design and provide PSSs throughout the lifecycle.

The comprehensive set of empirical data gathered and compiled through this process with an initial focus on lifecycle cost and value was reviewed and evaluated with a focus on Kjaer et al.'s [17] framework. This includes both identified quotes and the original transcriptions. Through pattern matching [50] with the newly-established circular supporting activities and the resource reduction enablers and PSS strategies proposed by Kjaer et al. [17], Kamiono's PSS design and provision was evaluated, and the basis for the data reported in Section 4 and discussed in Section 5 was isolated. To achieve this, the strategies, aims, and circular supporting activities served as benchmarks against which the attained understanding of Kamiono's PSS was assessed in an iterative process. Thus, the empirical data gathered provided the basis for the assessment and discussion of the potential contribution of Kamiono's PSS to resource decoupling towards a CE.

The manuscript of this article was provided to a central project member ( $R$ and $D$ Leader) at Kamiono for checking and feedback. The $\mathrm{R}$ and $\mathrm{D}$ Leader confirmed the accuracy of the representation of Kamiono's processes, strategies, and approaches.

\section{PSSs towards a CE-Status Quo, Assessment Framework, and Circular Supporting Activities}

The number of publications on the topic of the circular economy has increased tremendously in recent years-an unsurprising circumstance, considering how pressing the related issues have become [51]. In this section, the goal is to first provide a brief general overview of PSSs in the CE context and from this, to isolate key circular supporting activities to facilitate the assessment of the potential relative resource reduction through an industry-provided, use-oriented PSS in the scope of a CE. While the focus lay on publications explicitly referring to PSSs and a CE, other papers were included if relevant to the goal of establishing meaningful supporting activities to support the assessment of the potential CE contributions of PSSs. This approach, however, does not aim to provide an overview of the entirety of the state of the art on a CE. A number of recent reviews (see, e.g., [8,20,52-54]) are more apt at providing such insight.

\subsection{PSSs and a CE-A Brief Overview}

According to Khan et al. [55], PSSs can be described as a special case of servitization [38,39]: Where servitization as such is centered on businesses transforming themselves and their offerings, PSSs in the academic discourse have incorporated the precondition of a reduced environmental impact [1,4] from the outset, and other researchers have further stressed this aspect [30,56]. Spring and Araujo [18] have seen increasing congruency between environmentally-centered PSSs and a CE based on their review of the state of the art, while they criticize the existing focus on dematerialization and closed-loop supply chains, stating that a CE focus instead requires the "creation of novel network relationships involved in multiple activities such as reverse logistics [ ... ]" [18] (p.135). Similarly, Parida et al. [57] highlight the need for an orchestration of entire industrial ecosystems moving towards a circular economy instead of a focus on the level of the individual company. Witjes and Lozano [23] also place focus on actor collaboration in establishing and executing a sustainable business model, of which PSSs are seen as a vital archetype.

Going beyond only PSSs, terms such as sustainable business models [2] and circular business models [24] have been established. In this context, Bocken et al. [7] identify "deliver functionality, rather than ownership" as a critical sustainable business model archetype based on PSSs- and servitization 
literature, by, e.g., pointing out the potential of PSSs to break the link between production volume and profit. Michielini et al. [58] determine PSSs as a crucial facilitator of the transition from a linear to a circular economy while urging caution regarding the implementation of the offerings in industry practice and pointing out the need for a high level of product-service integration to achieve the desired benefits. Ritzén and Sandström [59] postulate that for PSSs to contribute to a CE, integration is not only needed between products and services but also within the manufacturing company towards increased internal collaboration. The need for a high level of integration between products and services for an offering to provide the opportunity for environmental benefits throughout the lifecycle has been pointed out in PSS-centric research predating the popularity of the CE term $[27,60,61]$.

PSSs are seen as a vital facilitator for retaining resource value towards a CE, e.g., by way of product sharing and the extension of the product lifetime $[17,62]$. Overall, PSSs and related business models are considered crucial for the implementation of CE strategies on a company level [22,23].

Therefore, attaining a deeper understanding of the potential reduction in relative and absolute resource consumption by real-world PSSs is timely. This serves to complement existing research efforts centered on environmental value propositions [15] with a focus on PSSs provided based on mostly economic motivations and without prescriptive support.

\subsection{Framework and Circular Supporting Activities to Assess the Potential CE Contribution of PSSs}

The assessment presented is based on the two-stage framework for the evaluation of the potential contribution of PSSs to resource decoupling in the scope of a CE proposed by Kjaer et al. [17]. Departing from an in-depth review, the authors proposed a two-step approach for the investigation of both relative resource reduction through PSS provision and thus, contributions to circular strategies, as well as the absolute decoupling of resource use and increased creation of customer value [17].

Figure 2 below details the adapted framework to assess the possible contribution of PSSs to both relative resource reduction and an absolute resource decoupling. Figure 2 further indicates the inclusion of the additional circular supporting activities established to structure and facilitate the assessment of the potential contributions of use-oriented PSSs to a CE.

Initially, to provide a comprehensive overview of the framework applied, its most important aspects as introduced by Kjaer et al. [17] are reiterated. However, for comprehensive insight, please refer to the original publication.

Kjaer et al. [17] established five PSS strategies based on a literature review, with the references used therein reiterated below.

1. Operational Support refers to the providers supporting the operation of the offering, e.g., through performance monitoring or personnel training $[2,63,64]$.

2. Product Component Maintenance focuses on the efficient and effective maintenance of product components of the PSS, e.g., by way of preventive maintenance, repair or upgrades [2,64-66].

3. In Product Sharing, the provider retains ownership and control of the physical components of the offering and ensures the sharing of resources between its users [64,67-69].

4. Take-Back/EoL Management is centered on the provider's role in determining the use of the PSS after the first lifecycle, e.g., through remanufacturing, refurbishment, recycling, etc. [2,64-66,70].

5. Optimized Result refers to a provider's delivery of a functional result leading to dematerialization and applies only to result-oriented PSSs [64,65], a concept recently called into question [71].

As shown in Figure 2, these strategies can contribute to the four PSS enablers of resource reduction proposed by Kjaer et al. [17] and slightly modified here to improve clarity in relation to traditional product sales. 


\section{Product-Service System}

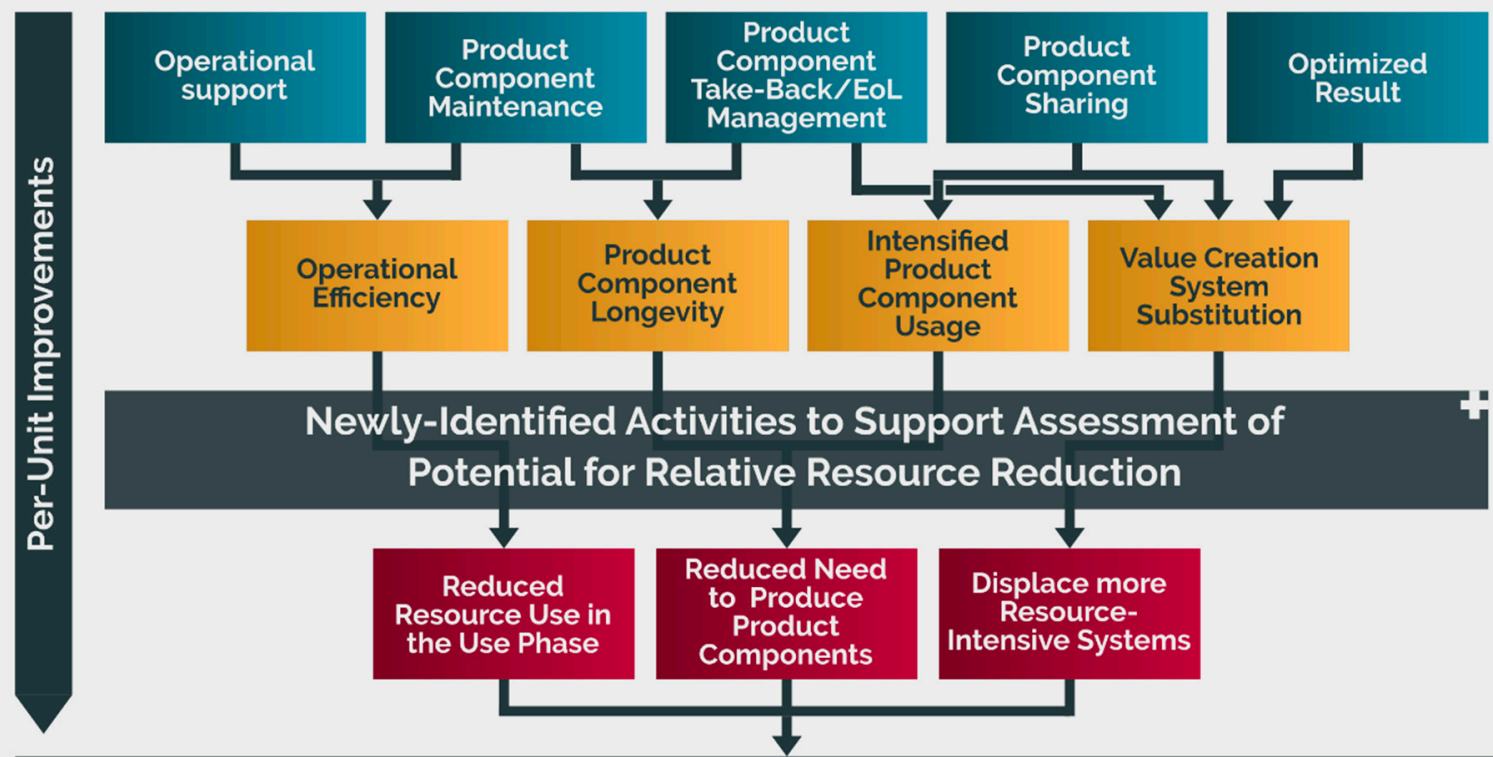

\section{Relative Resource Reduction based on Current Strategy}

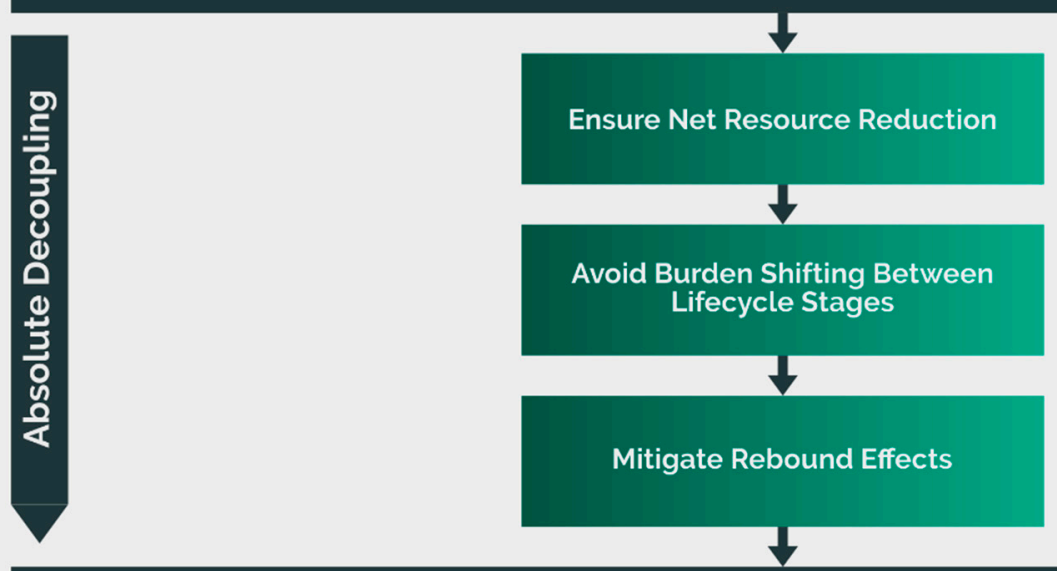

\section{Absolute Resource Decoupling}

\section{LEGEND}

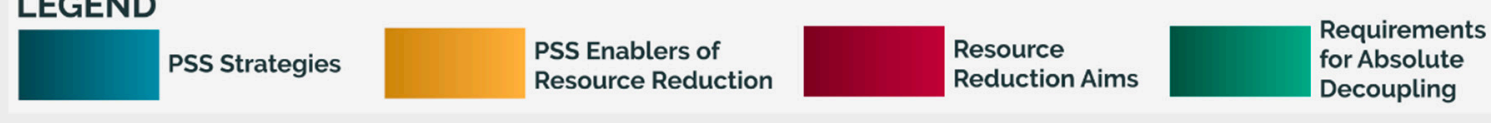

Figure 2. Adapted framework by Kjaer et al. [17].

For details on the impact of these enablers depending on the PSS business model employed, please see Kjaer et al. [17] (pp. 5, 6). As Kamiono provides use-oriented PSSs, these offerings are in exclusive focus here:

1. Operational Efficiency, which is described as being particularly relevant for PSSs with resource-intensive use phases. As the provider remains in the ownership of the physical components, this can give control over the maintenance and efficient operation.

2. Product Component Longevity in case of use-oriented PSSs is, according to Kjaer et al. [17], focused on intensified maintenance in the use phase and possible direct reuse of product components 
(e.g., through re-leasing). Beyond that, PSS design for longevity and robustness can be considered a critical aspect [34].

3. Intensified Product Component Usage is particularly focused on product sharing [61,69]. In the case of use-oriented PSSs, this refers to the sub-utilization of product components that are infrequently used.

4. Value Creation System Substitution has profound implications in the case of PSSs, while it is also severely limited in use-oriented cases: Although customer value is often created differently, and possibly with higher efficiency than in the case of product sales, the provider has no control over which overall solution is chosen by a customer.

Kjaer et al. [17] obtain three resource reduction aims based on these enablers. These are (partly adjusted) reduce the need for resources during the PSS's use phase, reduce the need for producing the product components, and displace more resource-intensive systems. These terms are later applied to the investigation of the CE-contribution of Kamiono's PSSs.

\subsubsection{Circular Supporting Activities to Assess Relative Resource Decoupling towards a CE}

Under reflection of the resource reduction enablers and strategies for PSSs introduced by Kjaer et al. [17], and using the results of the literature review conducted, support activities to facilitate the assessment of the potential contribution of PSSs to relative resource reduction towards a CE were established to tie into the framework as illustrated in Figure 2. The assessment of the degree to which a company applies these activities in its PSS offerings is intended to serve as a measuring stick to determine the potential contribution to resource decoupling towards a CE.

In order to facilitate the assessment of the application of the proposed circular supporting activities in industrial practice, a simple scale was developed. In the assessment of Kamiono's PSS, this is used to provide an at-a-glance overview of potential contribution to a relative resource reduction towards a $\mathrm{CE}$ as summarized in Section 4.1.4. For this, a scale of 0, 1, 2, 5 was selected to allow for prioritization when identifying improvement opportunities, similar to quality function deployment (see [72]).

- $\quad 0-$ Not applicable/no contribution to relative resource reduction.

- 1 -Low contribution to relative resource reduction.

- $\quad 2$-Notable contribution to relative resource reduction.

- 5-Substantial contribution to relative resource reduction.

To provide a concise overview, Table 2 introduces the newly-established activities and the references on which they are based. Further, the PSS strategies and resource reduction enablers that are operationalized through these activities are pointed out. Additionally, the most relevant lifecycle phases when aiming to apply a given activity are indicated. 
Table 2. Novel circular support activities to assess PSSs' potential contribution to relative resource reduction towards a CE (columns 4-6 adapted from [17]).

\begin{tabular}{|c|c|c|c|c|c|}
\hline $\begin{array}{l}\text { Activity to } \\
\text { Support PSSs' } \\
\text { Potential Relative } \\
\text { Resource } \\
\text { Reduction } \\
\text { towards a CE }\end{array}$ & Description of Activity if Fully Applied & References & $\begin{array}{l}\text { Supported PSSs } \\
\text { Strategies }\end{array}$ & $\begin{array}{l}\text { Relevant } \\
\text { Lifecycle } \\
\text { Phases }\end{array}$ & $\begin{array}{l}\text { Resource } \\
\text { Reduction } \\
\text { Aim }\end{array}$ \\
\hline $\begin{array}{l}\text { Implement } \\
\text { Performance } \\
\text { Monitoring and } \\
\text { Data-Driven } \\
\text { Maintenance }\end{array}$ & $\begin{array}{l}\text { PSS provider performs maintenance with a } \\
\text { focus on efficiency, ideally predictive, } \\
\text { data-driven maintenance. }\end{array}$ & {$[31,36,73,74]$} & $\begin{array}{l}\text { Operational } \\
\text { Support; Product } \\
\text { Component } \\
\text { Maintenance }\end{array}$ & Use & $\begin{array}{l}\text { Reduced } \\
\text { resource use in } \\
\text { the use phase }\end{array}$ \\
\hline $\begin{array}{l}\text { Support Efficiency } \\
\text { of Customers' Use }\end{array}$ & $\begin{array}{l}\text { PSS provider supports the customer in } \\
\text { using the offering with utmost efficiency. } \\
\text { This is a critical aspect for providers of } \\
\text { use-oriented PSSs, as these are } \\
\text { customer-operated and crucial to ensuring } \\
\text { highly efficient operation and low resource } \\
\text { use in the use phase. }\end{array}$ & {$[66,75-79]$} & $\begin{array}{l}\text { Operational } \\
\text { Support }\end{array}$ & Use & $\begin{array}{l}\text { Reduced } \\
\text { resource use in } \\
\text { the use phase }\end{array}$ \\
\hline $\begin{array}{l}\text { Adjust Incentives } \\
\text { with Lifecycle } \\
\text { Focus }\end{array}$ & $\begin{array}{l}\text { PSS-oriented internal incentives are } \\
\text { guiding the provider's activities } \\
\text { throughout all lifecycle phases. This } \\
\text { concerns, for example, typically conflicting } \\
\text { issues such as simultaneous efforts to } \\
\text { reduce production cost and use phase costs, } \\
\text { product-centric sales incentives and } \\
\text { incentives to "sell" services while internal } \\
\text { company divisions are billed in cases of } \\
\text { use-oriented PSSs. }\end{array}$ & {$[18,26-28,80]$} & $\begin{array}{l}\text { Operational } \\
\text { Support; Product } \\
\text { Component } \\
\text { Maintenance; } \\
\text { Product } \\
\text { Component } \\
\text { Take-Back/EoL } \\
\text { Management; } \\
\text { Product } \\
\text { Component } \\
\text { Sharing, } \\
\text { Optimized Result }\end{array}$ & $\begin{array}{l}\text { Design, } \\
\text { Use, EoL }\end{array}$ & $\begin{array}{l}\text { Reduced } \\
\text { resource use in } \\
\text { the use phase }\end{array}$ \\
\hline $\begin{array}{l}\text { Implement EoL } \\
\text { Management - } \\
\text { Reuse, } \\
\text { Remanufacturing, } \\
\text { Recycling }\end{array}$ & $\begin{array}{l}\text { The PSS provider ensures reuse, } \\
\text { remanufacturing or recycling (in order of } \\
\text { CE contribution) and thus, the use of the } \\
\text { physical components of the PSS in further } \\
\text { lifecycles. }\end{array}$ & {$[8,55,81]$} & $\begin{array}{l}\text { Product } \\
\text { Component } \\
\text { Take-Back/EoL } \\
\text { Management }\end{array}$ & $\begin{array}{l}\text { Design, } \\
\text { EoL }\end{array}$ & $\begin{array}{l}\text { Reduced need } \\
\text { to produce } \\
\text { product } \\
\text { components, } \\
\text { reduced } \\
\text { resource use in } \\
\text { the use phase }\end{array}$ \\
\hline $\begin{array}{l}\text { Adjust Design } \\
\text { Process for PSS } \\
\text { Design }\end{array}$ & $\begin{array}{l}\text { Specific, PSS-focused design process, } \\
\text { ensuring resource efficiency (decreasing } \\
\text { resource use per customer value created) } \\
\text { and effectiveness (intentional, purposeful } \\
\text { design for slowing and closing loops, } \\
\text { including 4R efforts (Reduce, Reuse, } \\
\text { Recycling, Remanufacturing)). }\end{array}$ & {$[11,30,66,68,82,83]$} & $\begin{array}{l}\text { Product } \\
\text { Component } \\
\text { Maintenance, } \\
\text { Product Sharing, } \\
\text { Take-Back/EoL }\end{array}$ & $\begin{array}{l}\text { Design, } \\
\text { Use, EoL }\end{array}$ & $\begin{array}{l}\text { Reduced need } \\
\text { to produce } \\
\text { product } \\
\text { components, } \\
\text { reduced } \\
\text { resource use in } \\
\text { the use phase }\end{array}$ \\
\hline $\begin{array}{l}\text { Enable Shared PSS } \\
\text { Use }\end{array}$ & $\begin{array}{l}\text { The physical components of a PSS are } \\
\text { relocated and distributed by the provider } \\
\text { based on the current customer needs, } \\
\text { increasing resource utilization. }\end{array}$ & {$[14,15,18,84-86]$} & $\begin{array}{l}\text { Product } \\
\text { Component } \\
\text { Sharing }\end{array}$ & Use & $\begin{array}{l}\text { Reduced need } \\
\text { to produce } \\
\text { product } \\
\text { components, } \\
\text { reduced } \\
\text { resource use in } \\
\text { the use phase }\end{array}$ \\
\hline $\begin{array}{l}\text { Execute } \\
\text { Customer-Value } \\
\text { Oriented } \\
\text { Substitution }\end{array}$ & $\begin{array}{l}\text { The value creation system of the PSSs is } \\
\text { substituted by a replacement with reduced } \\
\text { resource use, with the result creating the } \\
\text { same customer value. }\end{array}$ & {$[17,27]$} & $\begin{array}{l}\text { Displace more } \\
\text { resource intensive } \\
\text { systems }\end{array}$ & Use & $\begin{array}{l}\text { Displace more } \\
\text { resource-intensive } \\
\text { systems }\end{array}$ \\
\hline
\end{tabular}

\section{Assessing Kamiono's PSS for its Potential Contribution to a CE}

In this section, the results of the assessment are reported. First, Kamiono's PSS strategy, structure, and processes are assessed with respect to the identified circular support activities towards a potential relative resource reduction. A condensed summary of these results is provided in Table 3 in Section 4.1.4. After that, Kamiono's PSSs are investigated with a focus on absolute resource decoupling. 
Table 3. Results of assessing Kamiono with respect to the application of the activities and enablers of relative resource reduction (column 1 adapted from [17]).

\begin{tabular}{|c|c|c|c|}
\hline $\begin{array}{l}\text { Resource } \\
\text { Reduction } \\
\text { Enabler }\end{array}$ & $\begin{array}{l}\text { Activity to Support } \\
\text { PSSs' Potential Relative } \\
\text { Resource Reduction } \\
\text { towards a CE }\end{array}$ & $\begin{array}{l}\text { Kamiono's Strategy, Structure, and Processes towards } \\
\text { Designing and Providing PSSs }\end{array}$ & $\begin{array}{l}\text { PSSs' Potential } \\
\text { Contribution to } \\
\text { Relative Resource } \\
\text { Reduction towards a CE }\end{array}$ \\
\hline \multirow{3}{*}{$\begin{array}{l}\text { Operational } \\
\text { Efficiency }\end{array}$} & $\begin{array}{l}\text { Implement Performance } \\
\text { Monitoring and } \\
\text { Data-Driven } \\
\text { Maintenance }\end{array}$ & $\begin{array}{l}\text { - } \quad \text { Performance Monitoring System installed in all new } \\
\text { PSS offerings } \\
\text { - } \quad \text { Scheduled instead of data-driven maintenance } \\
\text { - } \quad \text { Lacking coherence and communication of data }\end{array}$ & (1) Low contribution. \\
\hline & $\begin{array}{l}\text { Support Efficiency of } \\
\text { Customers' Use }\end{array}$ & $\begin{array}{l}\text { - Customer personnel training offered with } \\
\text { PSS deployment } \\
\text { Evaluation and adjustments of customer premises to } \\
\text { ensure high efficiency and safety } \\
\text { - Performance Monitoring System allows the detection of } \\
\text { improper use } \\
\text { - Performance Monitoring System allows restricting use of } \\
\text { the offering only to authorized, trained staff and/or } \\
\text { functional check } \\
\text { Development towards further autonomy paves the way } \\
\text { for a further increase in efficiency in use }\end{array}$ & $\begin{array}{l}\text { (5) Substantial potential } \\
\text { contribution resulting } \\
\text { from Kamiono's } \\
\text { continued ownership } \\
\text { and control of physical } \\
\text { components. }\end{array}$ \\
\hline & $\begin{array}{l}\text { Adjust Incentives with } \\
\text { Lifecycle Focus }\end{array}$ & $\begin{array}{l}\text { - } \quad \text { Continued product sales-centric incentives } \\
\text { - A key target is lowered production cost; may lead to } \\
\text { shorted component lifespan in the use phase } \\
\text { - No calculation model to determine if increased } \\
\text { investment in design pays off throughout the lifecycle } \\
\text { - Remanufacturability not a key design target }\end{array}$ & $\begin{array}{l}\text { (1) Incentives remain } \\
\text { product focused; thus no } \\
\text { notable contribution can } \\
\text { be expected. }\end{array}$ \\
\hline $\begin{array}{l}\text { Product } \\
\text { Component } \\
\text { Longevity }\end{array}$ & $\begin{array}{l}\text { Adjust Design Process } \\
\text { for PSS Design }\end{array}$ & $\begin{array}{l}\text { - Currently, the same product components for sales and } \\
\text { PSS offerings } \\
\text { - Development of longevity-focused "PSS version" of } \\
\text { - } \quad \text { product components discussed but not in focus } \\
\text { - } \quad \text { No lifecycle focus during design stage at this point }\end{array}$ & $\begin{array}{l}\text { (0) As product } \\
\text { components are identical } \\
\text { in sales and PSSs, no } \\
\text { contribution can be } \\
\text { expected. }\end{array}$ \\
\hline $\begin{array}{l}\text { Intensified } \\
\text { Product } \\
\text { Component } \\
\text { Usage }\end{array}$ & Enable Shared PSS Use & $\begin{array}{l}\text { - Kamiono allows for short-term deployment of PSS } \\
\text { offerings within } 24 \text { hours } \\
\text { - } \quad \text { Long-term PSSs have fixed numbers of components } \\
\text { deployed for a fixed period } \\
\text { - No dynamic management of the number of units nor } \\
\text { relocation of units deployed in PSS offerings }\end{array}$ & $\begin{array}{l}\text { (2) Short-term PSS may } \\
\text { contribute; in connection } \\
\text { with PSS depends on } \\
\text { customer's planning. }\end{array}$ \\
\hline $\begin{array}{l}\text { Value Creation } \\
\text { System } \\
\text { Substitution }\end{array}$ & $\begin{array}{l}\text { Execute Customer-Value } \\
\text { Oriented Substitution }\end{array}$ & $\begin{array}{l}\text { - } \quad \text { Currently, use-oriented PSSs, therefore not possible } \\
\text { - Future result-oriented PSSs, towards customer as a black } \\
\text { box, would allow for continuous } \\
\text { efficiency improvements }\end{array}$ & $\begin{array}{l}(0) \text { Not applicable at } \\
\text { this time. }\end{array}$ \\
\hline
\end{tabular}

\subsection{The Potential Relative Resource Reduction through a Use-Oriented PSS towards a CE}

In this section, the PSS provision of the company Kamiono is described and analyzed with respect to the framework and the extent of the application of the circular supporting activities to assess PSSs' potential relative resource reduction in the scope of a CE. The assessment is presented based on the 
activities established in Section 3.2.1 and in relation to the resource reduction enablers proposed by Kjaer et al. [17].

\subsubsection{Resource Reduction Enabler Operational Efficiency}

Implement Performance Monitoring and Data-Driven Maintenance

Kamiono was a service-oriented company even before beginning to offer PSSs and continues to provide extensive services, depending on the customers' requirements, in connection to its product sales offerings. Concerning its PSS offerings, Kamiono recently began equipping all new units with sensor technology to monitor performance, regardless of if the customer requested and is willing to use this or not. This system records information regarding usage intensity and usage modes of the physical components, which is reported back to Kamiono.

However, the system is not equipped to allow for data-driven maintenance. In turn, as the project leader product data pointed out, all maintenance is performed according to a schedule rather than the actual need of the physical PSS components in the field. This causes substantial inefficiency because of parts being exchanged before they are worn out, unneeded technicians' travel and unnecessary downtime of the physical PSS components at the customer site in case of a breakdown.

Efficiency potential also lies in how the status of the physical components is communicated. As a quality engineer remarked, physical components at times arrive in workshops without a description of the errors earlier identified at the customer site, leading to an extensive effort to identify the said error. Further, a source of inefficiency is the lack of compatibility of data gathered in different markets, although the same overall PSSs are deployed, as remarked by a business development manager.

Overall, according to the scale proposed in Section 3.2.1, a low overall potential contribution (1) to relative resource reduction can be expected based on how this circular supporting activity is implemented at Kamiono.

\section{Supports Efficiency of Customers' Use}

Kamiono engages in extensive training with customer staff when a new PSS is deployed. This includes investigation and adjustment of the premises the PSS is used in and direct support for operating staff. Further, by way of its performance monitoring technology, Kamiono can identify inefficient use of the offering and the causes of damage, giving it the ability to inform the customers of this.

Through its monitoring technology, Kamiono can attribute damages to specific instances of customer behavior and request compensation, possibly leading to an even stronger learning effect. This may improve long-term efficiency. Lastly, Kamiono's performance monitoring technology, can, if desired by the customer, restrict the usage of the offering only to authorized and trained staff and is further capable of denying usage if a full check of all functions has not been performed.

A current trajectory for Kamiono is offering autonomous physical components, further reducing the possibility of accidental damage, inefficient use and reduced product component life, as a project manager working with automation, pointed out.

Based on Kamiono's application of this circular supporting approach, a substantial potential contribution (5) to a relative resource reduction is expected.

Adjust Incentives with a Lifecycle Focus

Kamiono's incentive structures remain focused on the product sales-centric portion of the business. This is exemplified by the fact that many practitioners have not recognized that spare parts are a cost rather than an income in case of PSS provision, as pointed out by a business solutions manager. Further, a project manager made clear that the central pressure remains on production cost, which can run contrary to efficient service, as it can lead to product components with shorter lifespans that are more difficult to repair. 
This current mismatch was emphasized by a project buyer, who highlighted that highly efficient service should be as equally important as low production cost. Regarding this, a R and D leader mentioned the lack of a robust calculation model at Kamiono indicating lifecycle efficiency, which would allow for a more expensive design when this is expected to reduce the total resource investments for all projected lifecycles of the offering.

The absence of lifecycle-focused incentives extends to EoL management. Remanufacturing is not considered in-depth at the design stage, as remarked by a design manager, which is surprising when considering that many of Kamiono's PSS offerings are provided through several consecutive use phases as short-term PSSs. These short-term PSS contracts are considered to provide particularly substantial opportunities to capture value, as a business solutions manager pointed out, further underlining the need for an incentive adjustment.

Generally, a low overall potential contribution (1) to a relative resource reduction must be expected.

\subsubsection{Resource Reduction Enabler Product Component Longevity}

Implement EoL Management—Reuse, Remanufacturing, Recycling

Kamiono has EoL management at the core of its PSS offering. After it receives the physical components (cores) of PSSs offerings at the end of the first lifecycle, checks are performed to determine their status. In the future, the goal is to make this process more efficient by utilizing the data gathered through the performance monitoring technology included in every PSS.

Depending on the status, product components are directly re-used (with as much as some new paint to restore the original look), remanufactured or usually only go towards parts reuse or recycling after several additional use phases. However, based on insight gathered with design phase practitioners, the focus on highly-efficient EoL performance could be further enhanced by a closer EoL focus at the design stage.

Although room for improvements remains, the application of this circular supporting activity at Kamiono indicates a substantial potential contribution (5) to a relative resource reduction.

\section{Adjust Design Process for PSS Design}

Kamiono currently does not carry out specific PSS design, meaning that product- and service design are not fully integrated, and a strong product focus remains. As an $R$ and D Leader pointed out, the cause for this lies in the historical focus on developing and selling products. The growing business coming from use-oriented PSSs is changing this, and the practitioner sees a need for spending more resources in adjusting the design focus.

The possibility of developing physical components with a specific focus on longevity exclusively for deployment as PSSs is discussed but not a current focus. This means that an identical physical basis is continued to be used for both product sales and PSSs. This can be seen as a result of still sales-centric incentives as mentioned above.

Although the focus on design for service and quality is strong, this focus does not extend to being able to accept an increased production cost for the benefit of reduced lifecycle cost, as the R and D leader further remarked. This situation leads to inefficiency concerning performance throughout the lifecycle, as does overlooking the benefits of increasing remanufacturing efficiency and thus, potentially further extending product component longevity.

Based on this assessment, the current design process at Kamiono likely yields no contribution (0) to a relative resource reduction towards a CE. 


\subsubsection{Resource Reduction Enabler Intensified Product Component Usage}

\section{Enable Shared PSS Use}

In general, Kamiono provides the capabilities related to this approach. Based on customer requests, the provider can deliver the needed product components to the customer's location within 24 hours. This is used by PSS customers to cover peak times in their business. However, Kamiono does not provide dynamic management of the physical components in its PSS offerings. Instead, usually a fixed contract length and the physical components included are defined at the sales stage. While increases based on the customer's current needs are possible, relocating hibernating physical components from one customer site to another is not carried out at this time.

The availability of short-term PSS indicates a potential notable contribution (2) to a relative resource reduction towards a CE with respect to how this supporting activity is currently applied at Kamiono.

\subsubsection{Resource Reduction Enabler Value Creation System Substitution}

Execute Customer Value-Oriented Substitution

As Kamiono currently provides use-oriented PSSs, a substitution for an alternative offering with reduced resources providing the same customer value is not possible. However, Kamiono is making efforts towards providing result-oriented offerings that would empower the company to make such decisions. A business development manager pointed out that customers are interested in these all-in-one solutions. This would allow Kamiono to offer a black box solution in which constant improvements and adjustments to the way customer value is created would be possible, enabling a substantial reduction in resource use.

However, as customer value-oriented substitutions are currently not possible, no contribution (0) to a relative resource reduction can be expected.

Table 3 summarizes the analysis of Kamiono's PSSs with respect to the resource reduction enablers and application of circular supporting activities with a focus on relative resource reduction in the scope of a CE. The numbers given in brackets in the last column indicate the potential contribution to relative resource reduction according to the 0,1, 2, 5-scale introduced in Section 3.2.1.

\subsection{Assessing Kamiono's PSS with a Focus on Absolute Decoupling}

After focusing on enablers of relative resource reduction and through PSSs, Kjaer et al. [17] point out a number of ways crucial to achieving absolute resource decoupling. Moving forward, the requirements proposed will be used to analyze Kamiono's current offering. However, it must be stated, that presenting a detailed analysis of Kamiono's PSS provision in this regard is challenging while preserving the anonymity of the company.

\subsubsection{Ensure Net Resource Reduction}

Kjaer et al. [17] introduce net resource reduction as a central requirement indicating the potential of a PSS to lead to absolute resource decoupling essential to arrive at a sustainable CE. The authors relate this to the relative resource reduction enablers introduced above except for value creation system substitution, and these shall briefly be analyzed in light of Kamiono's PSS below.

\section{Operational Efficiency}

Service-related processes (spare parts, monitoring equipment, etc.) must consume fewer resources than the resource consumption avoided in the system they are applied in, leading to a net resource reduction [17]. A closer focus on data-driven maintenance, increasing the quality of the data collected by the performance monitoring system and making use of this data throughout the use phase is needed to improve Kamiono's performance in this regard. The performance of Kamiono's PSSs with respect 
to applying the circular supporting activity support efficiency of customer's use is likely to lead to a notable relative resource reduction compared to product sales. However, in the status quo, scheduled maintenance and a lacking adjustment of internal incentive structures decrease the likelihood of a substantial net resource reduction concerning operational efficiency.

\section{Product Component Longevity}

Overall, to achieve a net resource reduction, fewer product components must be deployed while creating the same or more customer value. Kamiono's efforts regarding reduction, reuse, remanufacturing and recycling are likely to lead to fewer product components needing to be produced compared to product sales, where EoL management could hardly be applied. There is notable room for improvement in this regard concerning the provisions taken during design, though, as likely the net resource use could be decreased by making PSS-driven adjustments to the product components of the PSS offering.

\section{Intensified Product Component Usage}

Ensuring the market can accommodate the sharing of PSSs' product components and that customers are willing to share component utility is key [17]. As Kamiono finds itself in an expanding market and as the company is expanding its value capture more and more into what used to be the customers' sphere exclusively, it can be assumed that the market can accommodate shared PSSs use. A limiting factor may be time-criticality, as Kamiono promises to ensure delivery of PSSs with the desired product components on very short notice-a likely resource-intensive condition and detrimental to net resource reduction.

\subsubsection{Avoid Burden Shifting between Lifecycle Phases}

This is a critical aspect with respect to adjusting Kamiono's PSS design and provision: The aim of reduced resource need in the use phase by making adjustments in design will lead to increased resource use in production. Of course, the key then is ensuring that the resource reduction in the use phase is greater than the additional resource use in the production. For this, as observed by Kamiono engineering staff, a robust calculation model is critical.

Further, Kamiono is currently upgrading some of its product components for lower energy use, while the solution can be used to upgrade already deployed PSS offerings. This can serve to reduce the adverse effect of increased energy use resulting from greater product component longevity based on efforts to reduce the energy consumption of reused and remanufactured product components $[17,87]$.

Kjaer et al. [17] mention PSS design guidelines and tools as a way of coping with the complexity of adopting a true lifecycle perspective, while at Kamiono, the focus on economic performance and the history as a producer and seller of products makes the deployment of such methods and tools a challenge. To meet this task, the recommendations to improve the efficiency and effectiveness of PSS design and provision given resulting from the extensive research project conducted will be used as a point of reflection and to evaluate a currently ongoing design project. This can, of course, only be a starting point for adjustments on a larger scale.

\subsubsection{Mitigate Rebound Effects}

Rebound effects in the scope of PSSs towards a CE occur when PSSs bind less monetary resources than product sales providing similar customer value, and the remaining monetary resources are invested in other ways, which in turn consume further resources [88,89]. With respect to Kamiono's customers, this is likely a minor issue as its PSSs, rather than providing substantial cost savings, focus on the benefit of risk sharing, reduced bound capital and convenience for customers. However, irrespective of the room for improvement reported above, Kamiono is already a highly successful PSS provider. This and the expanding market the company finds itself in can increase the likelihood of rebound effects occurring. The mitigation opportunities for rebound effects occurring with PSS 
customers as reported by Kjaer et al. [17] based on Scheepens et al. [90] are, however, unlikely to be effective when the PSS provider is concerned. Therefore, rebound effects concerning the company are likely detrimental to the absolute resource decoupling aspired.

\section{Discussion and Ways Forward}

\subsection{Lessons Learned for PSSs' Potential Contribution to a CE in Terms of Relative and Absolute Resource Decoupling}

The results of the assessment will be discussed regarding their impact on the understanding of the contributions of PSSs to resource decoupling in the scope of a CE, first focusing on the circular supporting activities developed to facilitate the assessment of the potential relative resource reduction through PSSs.

A diverse picture emerged when assessing Kamiono's PSS provision in relation to the degree of application of the circular supporting activities established based on Kjaer et al.'s [17] framework.

\subsubsection{Identified Challenges and Opportunities at Kamiono towards Resource Decoupling}

This subsection discusses the areas where the contributions to resource decoupling towards a CE through Kamiono's PSS were found to retain substantial room for improvement.

Collecting, Handling and Utilizing Data

A critical aspect determining the potential reduction in resource use through PSSs when compared to product sales emerged to be data and its utilization. At first glance, this is unsurprising, as the expected impact of collecting and utilizing data is reported extensively in the literature to be vital to PSS provision (see, e.g., References $[18,36,73,91])$. Although the importance of collecting, evaluating and utilizing data is oft-mentioned, cases reporting the actual impact of such activities are still scarce [91].

In this context, the assessment reported regarding the impact of (and partly, lack thereof) the current strategy, structure, and processes of data collection and use in Kamiono's PSS design and provision may be considered a step forward, as it elucidates advancements achieved, but equally highlights substantial room for improvement. As current application of data collected using a performance monitoring system is limited to understanding usage intensity and usage modes, at this point, significant opportunities to further enhance efficiency remain unexploited: Kamiono continues to conduct scheduled instead of data-driven, condition-based maintenance efforts, and at this point, the data collected is not generally used in the design process as lessons learned. This may partly be caused by a lack of a lifecycle-centric calculation model for design, which then could be the recipient of such data. The same is true with respect to EoL management, where currently, data gathered during the use phase is hardly applied to ensure more efficient reuse or remanufacturing.

\section{Adjusting Incentives and Mindset}

A further essential aspect that emerged when assessing Kamiono's PSSs with respect to the activities proposed was the issue of incentives. Particularly since Kamiono is an industrial company and remains a product seller while also providing use-oriented PSSs, a fact common to many PSS providers [92,93], the incentive structures within the company have not been sufficiently adjusted to ensure the aspired resource decoupling towards a CE. Based on this, inefficiency was identified in all stages of the lifecycle: The design processes are not optimized for the requirements and potential of use-oriented PSS. Further, product-focused processes of sale and maintenance increase resource use based on an outdated focus on selling services. Lastly, room for improvement in reuse, remanufacturing, and additional lifecycles remains untapped due to a lacking availability and coherence of information of the cores' status.

As the shift in incentives caused by the increased responsibility of PSS providers is one of the key arguments brought forth in prior research discussing the potential contribution of PSSs to a CE $[4,27,28]$, this is a critical factor to be considered. A central hindrance for the much-needed adjustments within 
companies appears to be lacking internal awareness for this need [94]. In Kamiono's case, those directly working with PSS provision and many practitioners in design recognized this, but a comprehensive understanding of the attainable long-term economic advantages through adjusting incentives towards PSS design and provision could not yet be identified.

\subsubsection{Circularity Advancements at Kamiono and Potential Implications}

In contrast to the challenges above, focus areas emerged likely leading to resource reduction through Kamiono's PSSs compared to its current product sales. Kamiono has recognized the adverse impacts of improper use of the offering by customers, as the provider bears the economic impact of this. As this can be identified through the performance monitoring system and thus, be billed to the customer, it can be assumed that operational efficiency is enhanced. A counterargument, however, may be that this only serves to offset more inefficient use of offerings that are rented instead of owned [26,30,95], while additional recent insight supporting providers in mitigating these adverse effects is available [79].

Further, the efforts conducted in relation to reuse and remanufacturing are likely to lead to a resource reduction towards a CE, as this actually can displace the need for additional production and increases product component longevity.

It must be considered, though, that a unit sold to an end customer through product sales would very likely also receive maintenance and be sold on to additional customers in the case that the initial customer no longer needs it. In the face of this criticism, the PSS literature usually points to the unique knowledge the provider has about the offering [96], the ability to adjust the design to facilitate maintenance and longevity [30], and the ability to upgrade units already deployed [97] when clarifying efficiency gains related to maintenance through providers in the case of PSSs. These issues are also pointed out hereafter, increasing the likelihood of resource decoupling through Kamiono's PSSs.

On that note, as Kamiono conducts development efforts to increase the energy efficiency of the existing PSS deployed, it is likely the adverse effects of having outdated and less-efficient product components in the market (see [87]) can be mitigated. Remanufacturing has long been considered central for highly efficient PSS provision [98-100], and the case reported serves to highlight the impact of this. However, the lacking tie-in of remanufacturing to the design phase points to room for improvement that other industry actors may also consider.

Lastly, the availability of short-term PSS provision by Kamiono can serve to achieve resource decoupling through its PSSs offerings overall. If customers do plan prudently and ensure they only procure long-term PSSs to the extent they need, relying on short-term provision for peak times, this can be considered substantially advantageous and intensify product component usage.

However, even if customers have an unnecessary number of product components at their disposal in long-term PSSs, the adverse effect of unused resources hibernating at the customer's site may be offset partly by Kamiono's EoL activities: While unused components may lead to additional resource use, as the needs of other customers must be met, they also lead to increased product component longevity through reduced wear and tear in the unused, hibernating product components. Resulting from this, those product components may then be deployed for additional use phases after they have returned to Kamiono at the end of their first life.

Additionally, if data-driven maintenance was performed, the resource use through unused physical components could be further lowered. Based on this data, Kamiono may even suggest reducing the number of components deployed to a customer. A subsequent penalty for the reduction of units billed to the customer added to the potential reuse of the physical components would improve both economic performance and resource use in the scope of a CE.

\subsection{Broadly Relevant Lessons Learned as a Result of the Study Conducted}

Based on the assessment of Kamiono's PSSs for their contribution to a relative and absolute resource decoupling towards a CE, several lessons learned emerged. However, even here, there are no 
easy answers, particularly when conflicts between the economic goals of a company and the efficiencyand effectiveness-goals of a CE emerge.

When discussing the topic of data-driven maintenance and the decoupling potential therein, an $\mathrm{R}$ and $\mathrm{D}$ leader commented on the importance of regular service visits for the relationship with customers: For many customers, the service technicians are the main point of contact with Kamiono and based on technician input, at times, additional business can be generated. As exemplified by this, the goals of absolute decoupling, minimal resource use, and circularity can come into conflict with business driven by an economic focus under current economic paradigms.

In line with prior research, the capabilities of PSSs as a cornerstone of a future CE became clear, while the same is true of the challenges on that path [30,35]. As expected with integrated offerings such as PSSs, all aspects pertaining to the ability for resource decoupling of these offerings towards a $\mathrm{CE}$ are connected. In the case reported, this particularly concerns data, incentives, and design. Here, a practice-oriented consolidation of knowledge based on prior research may serve to enhance the potential of PSSs to contribute to a CE in industry practice.

Considering the goal of achieving absolute resource decoupling, the Kamiono study showed, that likely only result-oriented offerings can achieve that goal, as they ensure full provider flexibility in how customer value is created. Reflecting on the case at hand, a tremendous challenge in this regard is that Kamiono will continue to pursue a larger share of the market and an expansion of the market as such, considering the overall economic paradigm and the company's business environment. Kamiono's market expansion continues to result in an increasing number of product components deployed. Of course, efficiency improvements are always sought, but a move towards making circularity (i.e., contributing to a $\mathrm{CE}$ ) a central goal would likely require a comprehensive change in the overall resource strategy and revenue model (see Tunn et al. [42]). In the business to business-context Kamiono finds itself in, an increasing willingness to pay only on the promise of increased circularity or a sustainable value proposition is unlikely (see [85]).

Irrespective of the challenges, Kamiono is moving forward towards increasing integration. Lessons learned in the research collaboration on the basis of the results presented are applied to a development project at Kamiono to enhance the offering with a clearer lifecycle focus. The goal is to become better at structuring and using available data, collecting necessary additional data and applying this in design, use and EoL management for increased efficiency, effectiveness and therefore, a potentially improved congruency with a CE.

What remains is the central challenge of an economically-driven transition to PSSs and a limitation of all use-oriented PSSs: Providing more product components to customers continues to be economically advantageous, even if fewer components might be sufficient or an adjustment of, e.g., the customer's premises or adjusting customer processes may serve to reduce the need. This focus on expanding, producing and placing more physical components on the market is retained, and this constitutes the basis of much of the company's current workforce. For these challenges and hindrances to a CE, circumstances outside of Kamiono's reach need to change.

As prior research points out, policy must be adjusted [101,102], and incentives need to be adapted $[85,103]$ to highlight the benefits of resource decoupling not only on a relative basis, as done, e.g., through the ecodesign directive [104], but by encompassing all economic activity towards an absolute resource decoupling. Further, as pointed out by Kanda and Matschewsky [105], an application of the PSS concept to large technical systems and even on a societal level may be required in order to support the absolute decoupling needed to realize the resource reduction required to achieve the ambitious goals set [51].

\subsection{Limitations of the Study}

Although the state of the art on the contributions of real-world PSS to the CE could be expanded, the research presented suffers from some limitations: Only a single case could be assessed in the research reported. However, the case company Kamiono can be considered typical of industrial 
companies expanding to PSS in addition to, or replacing, product sales, which are often in focus of PSSs and CE-centric research. This enhances the transferability and applicability of the results reported. Further, the PSSs offered by Kamiono are use-oriented, missing some of the additional potential result-oriented offerings are expected to have, while recently, it has been questioned if technology enabling result-oriented PSSs are capable of doing so at this time [71].

An additional shortcoming is that the assessment is qualitative. To quantify the assessment performed, a detailed evaluation using, e.g., lifecycle assessment would be required [29], again confronted with its own shortcomings (see [15] referring to [66]). However, considering the fast-moving nature of Kamiono and similar PSS providers, by the time such an assessment would be available, it would already be outdated and reveal only little additional broadly relevant knowledge. As a result, the overall assessment performed, pointing out strengths as well as improvement opportunities, appears adequate and provides relevant insight for both practitioners and academics.

A further limitation of the study conducted is the consideration of Kamiono by itself, independent of competitors in the market able to create similar customer value as Kamiono. This makes passing final judgment on the potential of Kamiono's PSSs to contribute to resource decoupling towards a CE exceedingly difficult. The discussion above concludes that absolute resource decoupling resulting from Kamiono's use-oriented PSSs is unlikely, depending on the alternatives these offerings might be displacing on the market. Regardless, it cannot be ruled out that absolute decoupling is achieved in any case.

However, the reverse is also true: It is conceivable, that Kamiono's PSSs are, in fact, displacing much more circular and less resource-intensive offerings on the market, and therefore, make no positive contribution at all. It is the complex interrelations between a vast number of actors in an economy that makes passing judgment on better or worse solutions so difficult. This overall challenge is discussed in-depth by Zink and Geyer [103] when focusing on the issue of a circular economy rebound. Therein, the authors point out the dangers and misconceptions one can fall victim to if viewing the world exclusively as an engineering system and disregarding the underlying economic implications. To support researchers and practitioners in the future, this article has endeavored to shed further light on the challenges of assessing and understanding the potential contributions of PSSs to a CE.

\section{Conclusions and Outlook}

PSSs have been part of the academic discourse with a focus on environmental performance, resource efficiency and effectiveness for over two decades. However, many industrial companies with a history of producing and selling products become providers of PSS solely based on an economic motivation, be it based on customers' wish to sharpen their focus on core business [106,107] or in order for companies to expand their value capture into additional phases of the lifecycle $[108,109]$.

As the contributions of PSSs to a CE are much-discussed, an in-depth investigation of real-world PSS provision driven entirely by an economic motivation was a relevant research gap. This is reflected in the first research question "How can the potential contribution of a use-oriented PSS to a CE be assessed?" In response, the framework proposed by Kjaer et al. [17] was expanded and applied. The expansion through circular support activities is intended to facilitate and operationalize the assessment of the potential contribution of PSSs to absolute and relative resource decoupling towards a CE. While the support activities identified and the descriptions provided are mainly centered on use-oriented PSS, they may also bear relevance for the assessment of result-oriented offerings. However, the much more extensive possibilities for providers of result-oriented offerings to make adjustments towards relative and absolute resource decoupling warrant a broader investigation focused on alternative modes of creating customer value beyond the activities proposed here.

Further, to answer the second research question "What is the potential contribution of the PSS offering by the studied company to relative resource reduction and absolute resource decoupling of economic growth and resource use in the scope of a CE?", this article reported on an in-depth assessment of the use-oriented PSSs provided by the industrial company Kamiono, based on an extensive study. 
Kamiono's field of business is not inherently sustainability-centric, and the company is providing PSSs largely based on economic motivations. The company's strategy, structure, and processes towards PSSs were assessed by adopting Kjaer et al.'s [17] framework for the analysis of PSSs and their contribution to the CE through resource decoupling, which was further operationalized with circular supporting activities focused on use-oriented PSSs.

Concerning a relative resource reduction in contrast to traditional product sales, an ambiguous picture of Kamiono's current PSS provisions emerged. Strong points regarding the PSS' contribution to $\mathrm{CE}$ were identified in improvements in operational efficiency through customer training, in product component longevity through efforts in reuse and remanufacturing, and in intensified product component usage through the availability of short-term PSSs to cope with customers' peak loads. Room for improvement was found in lacking adjustment of internal incentives, design processes, and foci, and the gathering and use of data to increase the potential of resource decoupling based on PSS provision throughout all lifecycle phases.

Focusing on absolute resource decoupling, the assessment conducted showed that likely only result-oriented offerings, enabling value creation system substitution, can achieve this target. Any industrial company undergoing servitization will likely depart from its history and prior knowledge. Thus, to move closer towards a $\mathrm{CE}$, the initial question of any design process must be the fulfillment of a certain customer need and how this can be achieved most efficiently. Starting from a blank canvas in such a fashion is suspected to be a substantial challenge for industrial companies faced with path dependency and inertia.

The results reported are of interest for academia and industry practice alike: For academic readers, this article expands the fairly conceptual state of the art in PSSs' potential contributions to a CE with a real-world case and application of a previously established framework, increasing reflexivity in the field. Researchers are invited to expand upon or revise the use-oriented circular supporting activities proposed here as assessment criteria, and to carry out their own assessments on the basis of Kjaer et al.'s [17] framework in conjunction with the activities, in order to further expand the available knowledge base on real-world PSSs and their potential contribution to a CE.

For industry practitioners, the results reported indicate and reinforce previously identified insight on resource reduction through PSS provision throughout the lifecycle. The results further provide points of departure for own improvement efforts towards becoming a more efficient PSS provider.

Lastly, the question posed in the title of this article must be answered: Is there such a thing as unintended circularity? Can it be hoped that companies, focused on their own best interest, stumble upon solutions that benefit all when becoming PSS providers? Based on the results reported, there is hope: The better industry actors understand the benefits of being highly efficient and lifecycle focused, the more they can comply unintentionally with what academics understand to be characteristics of circular businesses. However, path dependency, inertia, lack of knowledge and partly, lacking creativity, will likely continue to hold many industrial actors back on the path to a CE if they do not walk it consciously. Moving forward, it is a crucial task for academics to make knowledge available in easy-to-access, easy-to-understand ways to contribute more effectively to alleviating this challenge.

Funding: This research was primarily funded by the case company Kamiono. The research was further supported by the Mistra REES (Resource-Efficient and Effective Solutions) program (No. 2014/16), funded by Mistra (The Swedish Foundation for Strategic Environmental Research).

Acknowledgments: The author wishes to thank the many practitioners at Kamiono for their participation in the different data-gathering sessions throughout the years, and for providing candid insight into the design and provision of product-service systems in practice. Here, Calle deserves particular mentioning and appreciation for his continued support of the project through these years. Thank you! A debt of gratitude is owed to Assoc.-Prof. Sara Gustafsson for her in-depth pre-submission review of this manuscript and the detailed feedback given to improve the draft. Further, Marianna Lena Kambanou deserves great thanks for her dedicated and driven work in the Kamiono project!

Conflicts of Interest: The research towards this article was partly funded by the company studied. However, company representatives have not attempted to suppress or influence the results presented and their discussion. 


\section{References}

1. Goedkoop, M.J.; Van Halen, C.J.G.; Te Riele, H.R.M.; Rommens, P.J.M. Product Service systems, Ecological and Economic Basics; Research Report 1999/36 Submitted to Ministerje van Volkshuisvesting; Ruimtelijke Ordening en Milieubeheer: The Hague, The Netherlands, 1999.

2. Bocken, N.M.P.; Short, S.W.; Rana, P.; Evans, S. A literature and practice review to develop sustainable business model archetypes. J. Clean. Prod. 2014, 65, 42-56. [CrossRef]

3. Yang, M.; Evans, S. Product-service system business model archetypes and sustainability. J. Clean. Prod. 2019, 220, 1156-1166. [CrossRef]

4. Mont, O. Clarifying the concept of product-service system. J. Clean. Prod. 2002, 10, 237-245. [CrossRef]

5. Kirchherr, J.; Reike, D.; Hekkert, M. Conceptualizing the circular economy: An analysis of 114 definitions. Resour. Conserv. Recycl. 2017, 127, 221-232. [CrossRef]

6. EMF. Towards a Circular Economy: Business Rationale for an Accelerated Transition; Ellen MacArthur Foundation: Cowes, UK, 2015.

7. Circle Economy. The Circularity Gap Report 2019; Circle Economy: Amsterdam, The Netherlands, 2019.

8. Lewandowski, M. Designing the business models for circular economy-towards the conceptual framework. Sustainability 2016, 8, 43. [CrossRef]

9. Reike, D.; Vermeulen, W.J.V.; Witjes, S. The circular economy: New or Refurbished as CE 3.0?-Exploring Controversies in the Conceptualization of the Circular Economy through a Focus on History and Resource Value Retention Options. Resour. Conserv. Recycl. 2018, 135, 246-264. [CrossRef]

10. Korhonen, J.; Nuur, C.; Feldmann, A.; Birkie, S.E. Circular economy as an essentially contested concept. J. Clean. Prod. 2018, 175, 544-552. [CrossRef]

11. Den Hollander, M.C.; Bakker, C.A.; Hultink, E.J. Product Design in a Circular Economy: Development of a Typology of Key Concepts and Terms. J. Ind. Ecol. 2017, 21, 517-525. [CrossRef]

12. Charter, M. (Ed.) Designing for the Circular Economy; Routledge: Abingdon, UK; New York, NY, USA, 2018; ISBN 9781315113067.

13. Bocken, N.M.P.; de Pauw, I.; Bakker, C.; van der Grinten, B. Product design and business model strategies for a circular economy. J. Ind. Prod. Eng. 2016, 33, 308-320. [CrossRef]

14. Moreno, M.; De los Rios, C.; Rowe, Z.; Charnley, F. A conceptual framework for circular design. Sustainability 2016, 8, 937. [CrossRef]

15. Manninen, K.; Koskela, S.; Antikainen, R.; Bocken, N.; Dahlbo, H.; Aminoff, A. Do circular economy business models capture intended environmental value propositions? J. Clean. Prod. 2018, 171, 413-422. [CrossRef]

16. McAloone, T.C.; Pigosso, D.C.A. Designing Product Service Systems for a Circular Economy. In Designing for the Circular Economy; Charter, M., Ed.; Routledge: Abingdon, UK, 2018; pp. 102-112.

17. Kjaer, L.L.; Pigosso, D.C.A.; Niero, M.; Bech, N.M.; McAloone, T.C. Product/Service-Systems for a Circular Economy: The Route to Decoupling Economic Growth from Resource Consumption? J. Ind. Ecol. 2019, 23, 22-35. [CrossRef]

18. Spring, M.; Araujo, L. Product biographies in servitization and the circular economy. Ind. Mark. Manag. 2017, 60, 126-137. [CrossRef]

19. Lieder, M.; Rashid, A. Towards circular economy implementation: A comprehensive review in context of manufacturing industry. J. Clean. Prod. 2016, 115, 36-51. [CrossRef]

20. Kalmykova, Y.; Sadagopan, M.; Rosado, L. Circular economy-From review of theories and practices to development of implementation tools. Resour. Conserv. Recycl. 2018, 135, 190-201. [CrossRef]

21. Rizos, V.; Behrens, A.; van der Gaast, W.; Hofman, E.; Ioannou, A.; Kafyeke, T.; Flamos, A.; Rinaldi, R.; Papadelis, S.; Hirschnitz-Garbers, M.; et al. Implementation of circular economy business models by small and medium-sized enterprises (SMEs): Barriers and enablers. Sustainability 2016, 8, 1212. [CrossRef]

22. Murray, A.; Skene, K.; Haynes, K. The Circular Economy: An Interdisciplinary Exploration of the Concept and Application in a Global Context. J. Bus. Ethics 2017, 140, 369-380. [CrossRef]

23. Witjes, S.; Lozano, R. Towards a more Circular Economy: Proposing a framework linking sustainable public procurement and sustainable business models. Resour. Conserv. Recycl. 2016, 112, 37-44. [CrossRef]

24. Nußholz, J.L.K. Circular business models: Defining a concept and framing an emerging research field. Sustainability 2017, 9, 1810. [CrossRef] 
25. Parida, V.; Wincent, J. Why and how to compete through sustainability: A review and outline of trends influencing firm and network-level transformation. Int. Entrep. Manag. J. 2019, 15, 1-19. [CrossRef]

26. Reim, W.; Parida, V.; Örtqvist, D. Product-Service Systems (PSS) business models and tactics-A systematic literature review. J. Clean. Prod. 2015, 97, 61-75. [CrossRef]

27. Tukker, A. Eight types of product-service system: Eight ways to sustainability? Experiences from SusProNet. Bus. Strateg. Environ. 2004, 13, 246-260. [CrossRef]

28. Davies, A.; Brady, T.; Hobday, M. Charting a path toward integrated solutions. MIT Sloan Manag. Rev. 2006, $43,39-48$.

29. Kjaer, L.L.; Pigosso, D.C.A.; McAloone, T.C.; Birkved, M. Guidelines for evaluating the environmental performance of Product/Service-Systems through life cycle assessment. J. Clean. Prod. 2018, 190, 666-678. [CrossRef]

30. Vezzoli, C.; Ceschin, F.; Diehl, J.C.; Kohtala, C. New Design Challenges to Widely Implement 'Sustainable Product-Service Systems'. J. Clean. Prod. 2015, 97, 1-12. [CrossRef]

31. Iung, B.; Levrat, E. Advanced maintenance services for promoting sustainability. Procedia CIRP 2014, 22, 15-22. [CrossRef]

32. Niero, M.; Hauschild, M.Z.; Hoffmeyer, S.B.; Olsen, S.I. Combining Eco-Efficiency and Eco-Effectiveness for Continuous Loop Beverage Packaging Systems: Lessons from the Carlsberg Circular Community. J. Ind. Ecol. 2017, 21, 742-753. [CrossRef]

33. Abukhader, S.M. Eco-efficiency in the era of electronic commerce - should "Eco-Effectiveness" approach be adopted? J. Clean. Prod. 2008, 16, 801-808. [CrossRef]

34. Matschewsky, J.; Kambanou, M.L.; Sakao, T. Designing and providing integrated product-service systems-challenges, opportunities and solutions resulting from prescriptive approaches in two industrial companies. Int. J. Prod. Res. 2018, 56, 2150-2168. [CrossRef]

35. Martinez, V.; Bastl, M.; Kingston, J.; Evans, S. Challenges in transforming manufacturing organisations into product-service providers. J. Manuf. Technol. Manag. 2010, 21, 449-469. [CrossRef]

36. Heyes, G.; Sharmina, M.; Mendoza, J.M.F.; Gallego-Schmid, A.; Azapagic, A. Developing and implementing circular economy business models in service-oriented technology companies. J. Clean. Prod. 2018, 177, 621-632. [CrossRef]

37. Ellen MacArthur Foundation (EMF). Growth Within: A Circular Economy Vision for a Competitive Europe; Ellen MacArthur Foundation: Cowes, UK, 2015.

38. Vandermerwe, S.; Rada, J. Servitization of business: Adding value by adding services. Eur. Manag. J. 1988, 6, 314-324. [CrossRef]

39. Baines, T.S.; Lightfoot, H.; Peppard, J.; Johnson, M.; Tiwari, A.; Shehab, E.; Swink, M. Towards an operations strategy for product-centric servitization. Int. J. Oper. Prod. Manag. 2009, 29, 494-519. [CrossRef]

40. Fischer-Kowalski, M.; Swilling, M.; von Weizsäcker, E.U.; Ren, Y.; Moriguchi, Y.; Crane, W.; Krausmann, F.; Eisenmenger, N.; Giljum, S.; Hennicke, P.; et al. Decoupling Natural Resource Use and Environmental Impacts from Economic Growth; United Nations Environment Programme: Nairobi, Kenia, 2011.

41. Onwuegbuzie, A.J.; Frels, R. Seven Steps to a Comprehensive Literature Review: A Multimodal Cultural Approach; SAGE Publications: Thousand Oaks, CA, USA, 2016; ISBN 9781446248928.

42. Tunn, V.S.C.; Bocken, N.M.P.; van den Hende, E.A.; Schoormans, J.P.L. Business models for sustainable consumption in the circular economy: An expert study. J. Clean. Prod. 2019, 212, 324-333. [CrossRef]

43. Lindahl, M.; Sakao, T.; Carlsson, E. Actors and System Maps for Integrated Product Service Offerings Practical Experience from Two Companies. Procedia CIRP 2014, 16, 320-325. [CrossRef]

44. Desai, A.; Lindahl, M.; Widgren, M. Actors and System Maps-A Methodology for Developing Product/Service Systems. In Sustainability through Innovation in Product Life Cycle Design; Matsumoto, M., Masui, K., Fukushige, S., Kondo, S., Eds.; Springer: Tokyo, Japan, 2017; pp. 217-232.

45. Flick, U. An Introduction to Qualitative Research; SAGE Publications: London, UK, 2009; ISBN 1446297713.

46. Patton, M.Q. Qualitative Research E Evaluation Methods; SAGE Publications: London, UK, 2002; ISBN 1483314812.

47. Krueger, R.A.; Casey, M.A. Focus Groups: A Practical Guide for Applied Research, 5th ed.; Sage Publications: Thousand Oaks, CA, USA, 2014; ISBN 1483365220.

48. Corbin, J.; Strauss, A. Basics of Qualitative Research: Techniques and Procedures for Developing Grounded Theory, 2nd ed.; Sage Publications: Thousand Oaks, CA, USA, 2008; Volume 3, ISBN 9781412906449. 
49. Glaser, B.G.; Strauss, A.L. The Discovery of Grounded Theory: Strategies for Qualitative Research; Aldine Transaction: New Brunswick, NJ, USA, 1967; ISBN 0202302601.

50. Yin, R.K. Case Study Research: Design and Methods; SAGE Publications: Thousand Oaks, CA, USA, 2013; ISBN 1483302008.

51. IPCC. Global Warming of $1.5^{\circ} \mathrm{C}$; IPCC: Geneva, Switzerland, 2018.

52. Merli, R.; Preziosi, M.; Acampora, A. How do scholars approach the circular economy? A systematic literature review. J. Clean. Prod. 2018, 178, 703-722. [CrossRef]

53. Geissdoerfer, M.; Savaget, P.; Bocken, N.M.P.; Hultink, E.J. The Circular Economy-A new sustainability paradigm? J. Clean. Prod. 2017, 143, 757-768. [CrossRef]

54. Lahti, T.; Wincent, J.; Parida, V. A definition and theoretical review of the circular economy, value creation, and sustainable business models: Where are we now and where should research move in the future? Sustainability 2018, 10, 2799. [CrossRef]

55. Khan, M.A.; Kalverkamp, M.; Wuest, T. Cascade Utilization During the End-of-Life of Product Service Systems: Synergies and Challenges. In Cascade Use in Technologies 2018; Springer: Berlin/Heidelberg, Germany, 2019; pp. 1-7.

56. Vezzoli, C.; Ceschin, F.; Diehl, J.C.; Kohtala, C. Why have "Sustainable Product-Service Systems" not been widely implemented? Meeting new design challenges to achieve societal sustainability. J. Clean. Prod. 2012, 35, 288-290. [CrossRef]

57. Parida, V.; Burström, T.; Visnjic, I.; Wincent, J. Orchestrating industrial ecosystem in circular economy: A two-stage transformation model for large manufacturing companies. J. Bus. Res. 2019. [CrossRef]

58. Michelini, G.; Moraes, R.N.; Cunha, R.N.; Costa, J.M.H.; Ometto, A.R. From Linear to Circular Economy: PSS Conducting the Transition. Procedia CIRP 2017, 64, 2-6. [CrossRef]

59. Ritzén, S.; Ölundh Sandström, G. Barriers to the Circular Economy-Integration of Perspectives and Domains. Procedia CIRP 2017, 64, 7-12. [CrossRef]

60. Manzini, E.; Vezzoli, C.; Clark, G. Product-Service Systems: Using an Existing Concept as a New Approach to Sustainability. J. Des. Res. 2001, 1. [CrossRef]

61. Baines, T.S.; Lightfoot, H.W.; Evans, S.; Neely, A.; Greenough, R.; Peppard, J.; Roy, R.; Shehab, E.; Braganza, A.; Tiwari, A.; et al. State-of-the-art in product-service systems. Proc. Inst. Mech. Eng. Part B J. Eng. Manuf. 2007, 221, 1543-1552. [CrossRef]

62. Bocken, N.M.P.; Olivetti, E.A.; Cullen, J.M.; Potting, J.; Lifset, R. Taking the Circularity to the Next Level: A Special Issue on the Circular Economy. J. Ind. Ecol. 2017, 21, 476-482. [CrossRef]

63. Pagoropoulos, A.; Kjaer, L.L.; Dong, Y.; Birkved, M.; McAloone, T.C. Economic and Environmental Impact Trade-Offs Related to In-Water Hull Cleanings of Merchant Vessels. J. Ind. Ecol. 2018, 22, 916-929. [CrossRef]

64. Bartolomeo, M.; dal Maso, D.; de Jong, P.; Eder, P.; Groenewegen, P.; Hopkinson, P.; James, P.; Nijhuis, L.; Örninge, M.; Scholl, G.; et al. Eco-efficient producer services-What are they, how do they benefit customers and the environment and how likely are they to develop and be extensively utilised? J. Clean. Prod. 2003, 11, 829-837. [CrossRef]

65. Manzini, E.; Vezzoli, C. Product-Service Systems and Sustainability: Opportunities for Sustainable Solutions; UNEP: Nairobi, Kenya, 2002; ISBN 92-807-2206-9.

66. Lindahl, M.; Sundin, E.; Sakao, T. Environmental and economic benefits of Integrated Product Service Offerings quantified with real business cases. J. Clean. Prod. 2014, 64, 288-296. [CrossRef]

67. Firnkorn, J.; Müller, M. What will be the environmental effects of new free-floating car-sharing systems? The case of car2go in Ulm. Ecol. Econ. 2011, 70, 1519-1528. [CrossRef]

68. Amaya, J.; Lelah, A.; Zwolinski, P. Design for intensified use in product-service systems using life-cycle analysis. J. Eng. Des. 2014, 25, 280-302. [CrossRef]

69. Mont, O. Reducing Life-Cycle Environmental Impacts through Systems of Joint Use. Greener Manag. Int. 2004, 63-77. [CrossRef]

70. Kerr, W.; Ryan, C. Eco-efficiency gains from remanufacturing: A case study of photocopier remanufacturing at Fuji Xerox Australia. J. Clean. Prod. 2001, 9, 75-81. [CrossRef]

71. Grubic, T.; Jennions, I. Do outcome-based contracts exist? The investigation of power-by-the-hour and similar result-oriented cases. Int. J. Prod. Econ. 2018, 206, 209-219. [CrossRef]

72. Franceschini, F.; Rupil, A. Rating scales and prioritization in QFD. Int. J. Qual. Reliab. Manag. 1999, 16, 85-97. [CrossRef] 
73. Bressanelli, G.; Adrodegari, F.; Perona, M.; Saccani, N. The role of digital technologies to overcome Circular Economy challenges in PSS Business Models: An exploratory case study. Procedia CIRP 2018, 73, $216-221$. [CrossRef]

74. Fargnoli, M.; Costantino, F.; Di Gravio, G.; Tronci, M. Product service-systems implementation: A customized framework to enhance sustainability and customer satisfaction. J. Clean. Prod. 2018, 188, 387-401. [CrossRef]

75. Mendoza, J.M.F.; Sharmina, M.; Gallego-Schmid, A.; Heyes, G.; Azapagic, A. Integrating Backcasting and Eco-Design for the Circular Economy: The BECE Framework. J. Ind. Ecol. 2017, 21, 526-544. [CrossRef]

76. Van Buren, N.; Demmers, M.; van der Heijden, R.; Witlox, F.; van Buren, N.; Demmers, M.; van der Heijden, R.; Witlox, F. Towards a Circular Economy: The Role of Dutch Logistics Industries and Governments. Sustainability 2016, 8, 647. [CrossRef]

77. Sundin, E.; Lindahl, M.; Ijomah, W. Product design for product/service systems. J. Manuf. Technol. Manag. 2009, 20, 723-753. [CrossRef]

78. Isaksson, O.; Larsson, T.C.; Rönnbäck, A.O. Development of product-service systems: Challenges and opportunities for the manufacturing firm. J. Eng. Des. 2009, 20, 329-348. [CrossRef]

79. Reim, W.; Sjödin, D.; Parida, V. Mitigating adverse customer behaviour for product-service system provision: An agency theory perspective. Ind. Mark. Manag. 2018, 74, 150-161. [CrossRef]

80. Rashid, A.; Asif, F.M.A.; Krajnik, P.; Nicolescu, C.M. Resource Conservative Manufacturing: An essential change in business and technology paradigm for sustainable manufacturing. J. Clean. Prod. 2013, 57, 166-177. [CrossRef]

81. Prendeville, S.; Bocken, N. Design for Remanufacturing and Circular Business Models. In Sustainability through Innovation in Product Life Cycle Design Part of the Series EcoProduction; Springer: Singapore, 2016; pp. 269-283. ISBN 978-981-10-0469-8.

82. Saidani, M.; Yannou, B.; Leroy, Y.; Cluzel, F. How to Assess Product Performance in the Circular Economy? Proposed Requirements for the Design of a Circularity Measurement Framework. Recycling 2017, 2, 6. [CrossRef]

83. Vezzoli, C.; Kohtala, C.; Srinivasan, A.; Xin, L.; Fusakul, M.; Sateesh, D.; Diehl, J.C. Product-Service System Design for Sustainability; Greenleaf Publishing: Sheffield, UK, 2014; ISBN 1783530790.

84. Manzini, E.; Vezzoli, C. A strategic design approach to develop sustainable product service systems: Examples taken from the 'environmentally friendly innovation' Italian prize. J. Clean. Prod. 2003, 11, 851-857. [CrossRef]

85. Urbinati, A.; Chiaroni, D.; Chiesa, V. Towards a new taxonomy of circular economy business models. J. Clean. Prod. 2017, 168, 487-498. [CrossRef]

86. Kane, G.M.; Bakker, C.A.; Balkenende, A.R. Towards design strategies for circular medical products. Resour. Conserv. Recycl. 2018, 135, 38-47. [CrossRef]

87. Gutowski, T.G.; Sahni, S.; Boustani, A.; Graves, S.C. Remanufacturing and Energy Savings. Environ. Sci. Technol. 2011, 45, 4540-4547. [CrossRef] [PubMed]

88. Binswanger, M. Technological progress and sustainable development: What about the rebound effect? Ecol. Econ. 2001, 36, 119-132. [CrossRef]

89. Ceschin, F.; Gaziulusoy, I. Evolution of design for sustainability: From product design to design for system innovations and transitions. Des. Stud. 2016, 47, 118-163. [CrossRef]

90. Scheepens, A.E.; Vogtländer, J.G.; Brezet, J.C. Two life cycle assessment (LCA) based methods to analyse and design complex (regional) circular economy systems. Case: Making water tourism more sustainable. J. Clean. Prod. 2016, 114, 257-268. [CrossRef]

91. Pagoropoulos, A.; Pigosso, D.C.A.; McAloone, T.C. The Emergent Role of Digital Technologies in the Circular Economy: A Review. Procedia CIRP 2017, 64, 19-24. [CrossRef]

92. Kowalkowski, C.; Windahl, C.; Kindström, D.; Gebauer, H. What service transition? Rethinking established assumptions about manufacturers' service-led growth strategies. Ind. Mark. Manag. 2015, 45, 59-69. [CrossRef]

93. Lenka, S.; Parida, V.; Sjödin, D.R.; Wincent, J. Towards a multi-level servitization framework: Conceptualizing ambivalence in manufacturing firms. Int. J. Oper. Prod. Manag. 2018, 38, 810-827. [CrossRef]

94. Lenka, S.; Parida, V.; Sjödin, D.R.; Wincent, J. Exploring the microfoundations of servitization: How individual actions overcome organizational resistance. J. Bus. Res. 2018, 88, 328-336. [CrossRef] 
95. Barquet, A.P.B.; de Oliveira, M.G.; Amigo, C.R.; Cunha, V.P.; Rozenfeld, H. Employing the business model concept to support the adoption of product-service systems (PSS). Ind. Mark. Manag. 2013, 42, 693-704. [CrossRef]

96. Thenent, N.E.; Settanni, E.; Sandborn, P.; Newnes, L.B. Maintenance within Product Service Systems: Is technical knowledge enough to link performance and cost? In Proceedings of the Maintenance Performance Measurement and Management Conference, Lappeenranta, Finland, 12-13 September 2013.

97. Matschewsky, J.; Sakao, T.; Khanagha, S.; Elfving, S.W. What's in it for the Provider? The Case of a Telecom Vendor's Value Capturing from the Transition to Product-Service Systems. Procedia CIRP 2016, 47, 6-11. [CrossRef]

98. Sundin, E.; Östlin, J.; Öhrwall Rönnbäck, A.; Lindahl, M.; Sandström, G. Remanufacturing of Products used in Product Service System Offerings. In Manufacturing Systems and Technologies for the New Frontier SE-110; Mitsuishi, M., Ueda, K., Kimura, F., Eds.; Springer: London, UK, 2008; pp. 537-542. ISBN 978-1-84800-266-1.

99. Sakao, T.; Mizuyama, H. Understanding of a product/service system design: A holistic approach to support design for remanufacturing. J. Remanuf. 2014, 4, 1-24. [CrossRef]

100. Sundin, E.; Bras, B. Making functional sales environmentally and economically beneficial through product remanufacturing. J. Clean. Prod. 2005, 13, 913-925. [CrossRef]

101. Drabe, V.; Hübner, R.; Herstatt, C. Analyzing Barriers to Corporate Implementation of the Circular Economy Concept-An Exploratory Approach. In Proceedings of the Social and Sustainable Innovation; Wulfsberg, J., Redlich, T., Moritz, M., Eds.; Helmut-Schmidt-University: Hamburg, Germany, 2016; pp. 53-63.

102. De Jesus, A.; Mendonça, S. Lost in Transition? Drivers and Barriers in the Eco-innovation Road to the Circular Economy. Ecol. Econ. 2018, 145, 75-89. [CrossRef]

103. Zink, T.; Geyer, R. Circular Economy Rebound. J. Ind. Ecol. 2017, 21, 593-602. [CrossRef]

104. European Council; European Parliament. Directive 2009/125/EC Establishing a Framework for the Setting of Ecodesign Requirements for Energy-Related Products; Official Journal of the European Union: Strasbourg, France, 2009; pp. 285/10-285/35.

105. Kanda, W.; Matschewsky, J. An exploratory expansion of the concept of product-service systems beyond products and services. Procedia CIRP 2018, 73, 185-190. [CrossRef]

106. Annarelli, A.; Battistella, C.; Nonino, F. Product service system: A conceptual framework from a systematic review. J. Clean. Prod. 2016, 139, 1011-1032. [CrossRef]

107. Brambila-Macias, S.A.; Sakao, T.; Kowalkowski, C. Bridging the gap between engineering design and marketing: Insights for research and practice in product/service system design. Des. Sci. 2018, 4, e7. [CrossRef]

108. Grönroos, C.; Voima, P. Critical service logic: Making sense of value creation and co-creation. J. Acad. Mark. Sci. 2013, 41, 133-150. [CrossRef]

109. Geissdoerfer, M.; Vladimirova, D.; Evans, S. Sustainable business model innovation: A review. J. Clean. Prod. 2018, 198, 401-416. [CrossRef]

(C) 2019 by the author. Licensee MDPI, Basel, Switzerland. This article is an open access article distributed under the terms and conditions of the Creative Commons Attribution (CC BY) license (http://creativecommons.org/licenses/by/4.0/). 